\title{
Article
}

http://dx.doi.org/10.11646/phytotaxa.278.2.1

\section{Molecular and Morphological Diversity of Lithothamnion spp. (Hapalidiales, Rhodophyta) from Deepwater Rhodolith Beds in the Northwestern Gulf of Mexico}

\author{
JOSEPH L. RICHARDS ${ }^{1, *}$, TALITA VIEIRA-PINTO ${ }^{2}$, WILLIAM E. SCHMIDT ${ }^{1}$, THOMAS SAUVAGE ${ }^{1}$, PAUL W. \\ GABRIELSON $^{3}$, MARIANA C. OLIVEIRA $^{2} \&$ SUZANNE FREDERICQ $^{1}$ \\ ${ }^{1}$ University of Louisiana at Lafayette, Biology Department, Lafayette, LA 70504-3602, U.S.A. \\ ${ }^{2}$ University of São Paulo, Biosciences Institute, Botany Department, Rua do Matão 277, 05508-090, São Paulo, SP, Brazil. \\ ${ }^{3}$ University of North Carolina at Chapel Hill, Biology Department, Chapel Hill, NC 27599-3280, U.S.A. \\ *Email: Joer207@gmail.com (Corresponding Author) \\ This article is dedicated in loving memory to Dr. Rafael Riosmena-Rodríguez.
}

\begin{abstract}
In the Northwestern Gulf of Mexico (NWGMx), subtidal rhodolith beds offshore Louisiana at 45-80 m depth harbor a diverse community of uncharacterized non-geniculate coralline algae including both biogenic and autogenic rhodoliths and other encrusting taxa. Identifying specimens to their correct genus and species is an ongoing process because many available names remain to be validated by comparison to type specimens. Here, comparative DNA sequencing (psbA, UPA, and COI) and scanning electron microscopy (SEM) are used to assess the molecular and morphological diversity of the rhodolithforming specimens belonging to the generic concept of Lithothamnion. Phylogenetic and species delimitation analyses of the newly generated sequences from recently dredged specimens at Ewing and Sackett Banks offshore Louisiana reveal the presence of at least six species of Lithothamnion, whose generic placement is confirmed by SEM images of features considered characteristic for the genus. More broadly, our analyses indicate at least eight Lithothamnion species are found in the Gulf of Mexico. Phylogenetic analyses of single ( $p s b \mathrm{~A}$ and COI) and concatenated markers ( $p s b \mathrm{~A}, \mathrm{COI}$ and UPA) show that Lithothamnion is polyphyletic.
\end{abstract}

Key words: ABGD, cryptic diversity, GMYC, Hapalidiaceae, Melobesioideae, polyphyly

\section{Abbreviations}

$\mathrm{BS}=$ bootstrap value; GMx $=$ Gulf of Mexico; NEGMx = northeastern Gulf of Mexico; NWGMx $=$ northwestern Gulf of Mexico; $\mathrm{PP}=$ posterior probability; $\mathrm{SEM}=$ Scanning Electron Microscope; SEGMx = southeastern Gulf of Mexico; SWGMx $=$ southwestern Gulf of Mexico; UPA =Universal Plastid Amplicon; WTA = Western Tropical Atlantic

\section{Introduction}

The NWGMx offshore Louisiana harbors subtidal rhodolith beds at depths of 45-80m comprising a diverse assemblage of non-geniculate coralline algae spanning all three orders Corallinales, Sporolithales and Hapalidiales (Richards et al. 2014, Fredericq et al. 2014, Krayesky-Self et al. 2016, Richards 2016). These rhodolith communities consist of free-living marine nodules primarily accreted by coralline algae precipitating calcium carbonate, the biogenic rhodoliths (Foster 2001), and secondarily colonized nodules of geobiological origin, referred to as autogenic rhodoliths (Fredericq et al. 2014). The latter begin as calcium carbonate nodules formed by differential erosion of cap rock that originated from anaerobic bacteria acting on the minerals within the underlying salt domes, which subsequently become overgrown by a suite of encrusting macroalgae, e.g., members of the coralline algal orders (see above), the red algal order Peyssonneliales and the brown algal order Dictyotales (Gore 1992, Fredericq et al. 2014). These rhodolith beds harbor a diverse assemblage of Bivalvia (Turgeon et al. 2009), whose shells provide additional substrata for encrusting coralline algae (Richards et al. 2014). 
Lithothamnion Heydrich (1897) is conserved against Lithothamnium Philippi (1837). Philippi(1837) based his genus Lithothamnium on five specimens of "rigid calcareous plants" from the Sicilian coast, Mediterranean Sea (Woelkerling 1983, p. 165). Four of these were newly described species (L. crassum Philippi, L. gracilis Philippi, L. ramulosum Philippi, and L. rubrum Philippi). The fifth species was L. byssoides (Lamarck) Philippi (Woelkerling 1983). Philippi merged the taxa Nullipora byssoides Lamarck and Millepora polymorphya var. globosa Esper (previously considered to be animals by Lamarck and Esper) into Lithothamnium. Philippi also synonymized both taxa, assigned the specific epithet byssoides based on priority, and assigned this specific epithet to one of the five specimens in his Sicilian collection (Woelkerling 1983, p. 165). Philippi's original description was later augmented by subsequent authors (e.g., Heydrich 1897b, Mason 1953), but especially by Adey (1966) who gave us our modern concept of Lithothamnion (as Lithothamnium) characterized as follows: 1) multiporate tetrasporangial conceptacles, 2) spermatangia in dendroid clusters completely covering male conceptacle walls, 3) a multilayered, non-coaxial hypothallium, 4) perithallial cells nearly at their maxiumum length when cut off from intercalary meristem cells, and 5) epithallial cells single layered, non-photosynthetic and "angular" (reviewed in Woelkerling 1983) that are sometimes referred to as being "flattened and flared" (Woelkering, 1988 p. 171) or "armored" (Adey et al. 2015). This later concept of Lithothamnium, however, was not based on any material from Philippi's original collection, whose whereabouts was unknown until found in Kützing's herbarium in 1980 by Woelkerling (1983). None of the specimens in Philippi's original collection possessed multiporate tetrasporangial conceptacles, and thus all of Philippi's (1837) Lithothamnium species belonged to other generic concepts (Woelkerling 1983). Because the modern concept of Lithothamnium had been adopted by many authors (albeit with some disagreement about how the genus was circumscribed) and many described species were named following that concept, Woelkerling (1983, pp. 193-194) proposed conservation of Lithothamnion Heydrich, noting that Heydrich (1897b) first used the presence of multiporate tetrasporangial conceptacles as a defining character. Lithothamnion muelleri Lenormand ex Rosanoff (1866) is the generitype species (type locality near Victoria, Australia).

Few studies have been conducted on Lithothamnion in the GMx (Dawes 1974, Minnery 1990, Mateo-Cid et al. 2014b), and these relied solely on thallus morpho-anatomy to distinguish species. Excluding taxa since transferred to other genera, Dawes (1974) reported one species of Lithothamnion, L. sejunctum Foslie (type locality: Christiansted, St. Croix), from offshore the west coast of Florida. Minnery (1990) reported Lithothamnion sp. A, B and 'Lithothamnium sejunctum?' in a preliminary investigation on the diversity and zonation of non-geniculate coralline algae in the NWGMx at the Flower Garden Banks National Marine Sanctuary offshore Texas. Mateo-Cid et al. (2014b) reported three species, L. occidentale (Foslie) Foslie (type locality: Crux Bay, St. Jan, Danish West Indies, now Cruz Bay, St. John Island, U.S. Virgin Islands), L. sejunctum, and L. crispatum Hauck (type locality: Rovigno, Adriatic Sea), from offshore the SWGMx near Campeche Banks and from the intertidal zone along the Atlantic coast of Mexico. Recently, Krayesky-Self et al. (2016) reported two unnamed species of Lithothamnion from the NWGMx and provided the first published $p s b$ A sequence of Lithothamnion from this location.

Recent DNA-based studies have shown a wealth of previously undocumented diversity for the three orders of non-geniculate coralline algae in the North Pacific Ocean (Adey et al. 2015), the North Atlantic Ocean (Peña et al. 2015, Peña et al. 2014a, Pardo et al. 2014), the Caribbean Sea (Hernández-Kantun et al. 2016, Peña et al. 2014b), the South Atlantic (Bahia et al. 2014, Sissini et al. 2014, Vieira-Pinto et al. 2014) as well as in the GMx (Mateo-Cid et al. 2014a, Richards et al. 2014, Krayesky-Self et al. 2016) and the Gulf of California (Hernández-Kantún et al. 2015). These studies demonstrated the importance of integrating DNA sequences with morpho-anatomical studies when assessing biodiversity, and provided a preliminary reference framework for comparison with newly generated data.

Following the April 2010 Deepwater Horizon oil spill, seven box-dredging expeditions conducted in NWGMx rhodolith beds for the purpose of biomonitoring led to comparative DNA sequencing and morpho-anatomical analyses of non-geniculate coralline algal specimens (Fredericq et al. 2014, Richards et al. 2014, Krayesky-Self et al. 2016). Often non-geniculate corallines were the only visible algal species present in post-spill dredges and a substantial portion of these specimens identified as members of the subfamily Melobesiodeae (Hapalidiaceae, Hapalidiales) awaited further investigations (Fredericq et al. 2014). Herein we focus on the molecular and morphological characterization of six unnamed Lithothamnion species from these NWGMx collections based on phylogenetic analyses of DNA sequence data and high magnification imaging of thallus anatomy using scanning electron microscopy (SEM). 


\section{Material and methods}

Specimens (Table 1) were collected with an Hourglass-design box dredge using minimum tow periods, usually 10 minutes or less (Joyce \& Williams 1969), deployed by the $R / V$ Pelican, the UNOLS (University-National Oceanographic Laboratory System) research vessel stationed at LUMCON (Louisiana Universities Marine Consortium), during seven post-Deepwater Horizon oil spill (DWH) expeditions in the vicinity of Ewing Bank ( $28^{\circ} 05.737^{\prime} \mathrm{N}$; 91 $\left.{ }^{\circ} 01.608^{\prime} \mathrm{W}\right)$ and Sackett Bank ( $\left.28^{\circ} 38.019^{\prime} \mathrm{N} ; 8^{\circ} 33.262^{\prime} \mathrm{W}\right)$ (see Felder et al. 2014, fig. 1, for map of collection sites). Expedition collection dates were December 2-6, 2010; April 19-24, 2011; August 26-30, 2011; August 24-26, 2012; November 15-17, 2012; October 17-22, 2013; and September 7-14, 2014. During the September 2014 cruise, samples were also collected offshore Florida in the SEGMx in the vicinity of the Dry Tortugas. Collected specimens were desiccated in silica gel aboard the $R / V$ Pelican and/or preserved in 5\% formalin/seawater, and deposited in the University of Louisiana at Lafayette Herbarium (LAF). Another portion of the samples was transported to the laboratory as "live rocks" (Delbeek \& Sprung 2005) and grown in 75-liter microcosm tanks prior to harvesting and preservation as described in Fredericq et al. (2014), Richards et al. (2014) and Felder et al. (2014). Exploratory DNA sequencing and SEM imaging led to the identification of eight specimens from the NWGMx belonging to the genus Lithothamnion. For phylogeographic context, additional sequences generated from three rhodolith-forming samples of Lithothamnion from the surrounding areas of the GMx (vicinity of the Florida Middle Grounds in the NEGMx, Campeche Banks in the SWGMx, and near the Dry Tortugas areas in the SEGMx) were also included as well as two samples from Pacific Panama and three samples from the Brazilian states of Ceará and Bahia (WTA).

TABLE 1. Collection data of voucher specimens and GenBank accession numbers for newly generated sequences and sequences of referenced studies included in the analyses of this study. Newly generated sequences shown in boldface. Sequences included in the multigene analysis shown in italics. *Not analyzed in present study.

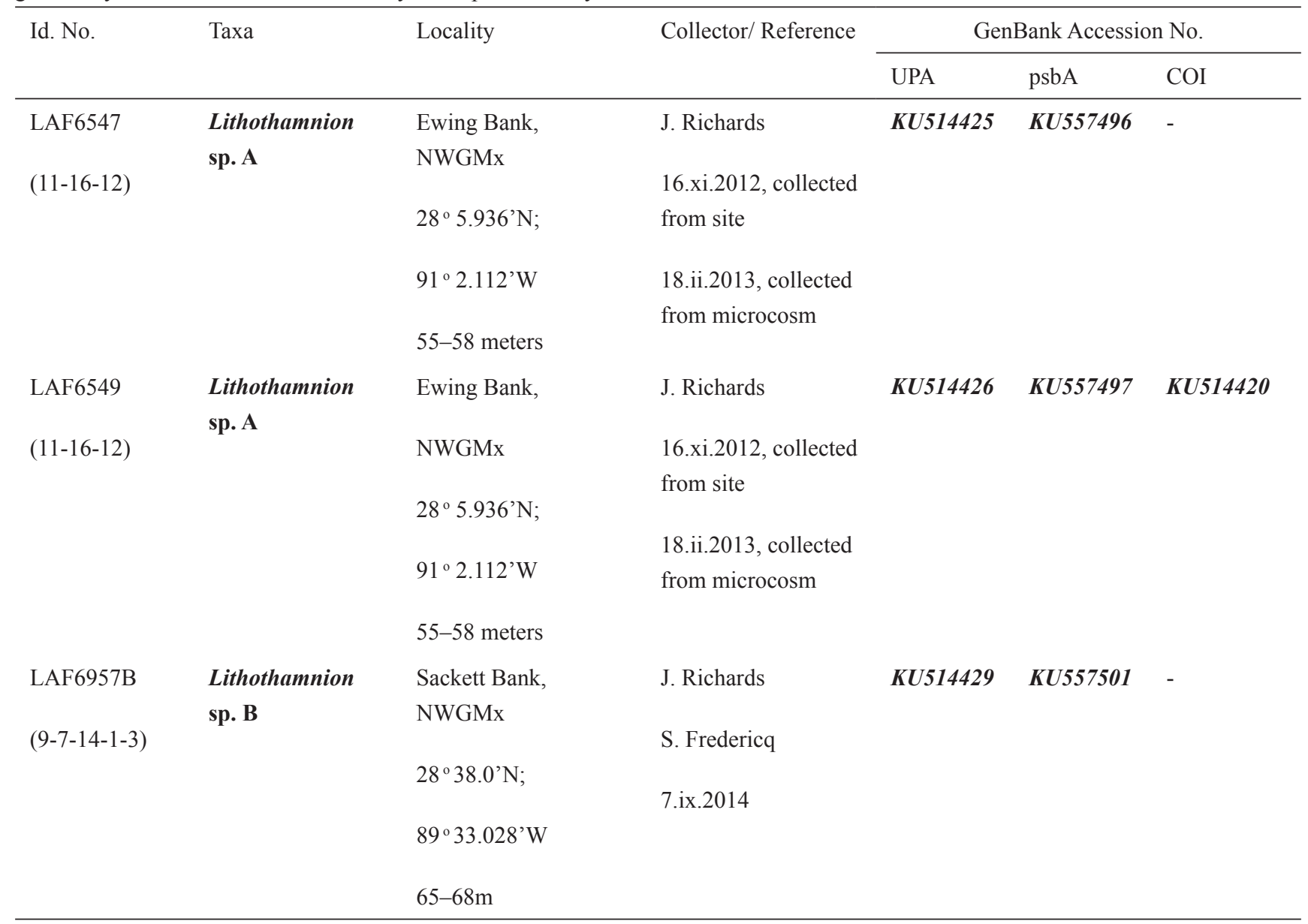

...Continued on next page 
TABLE 1. (Continued)

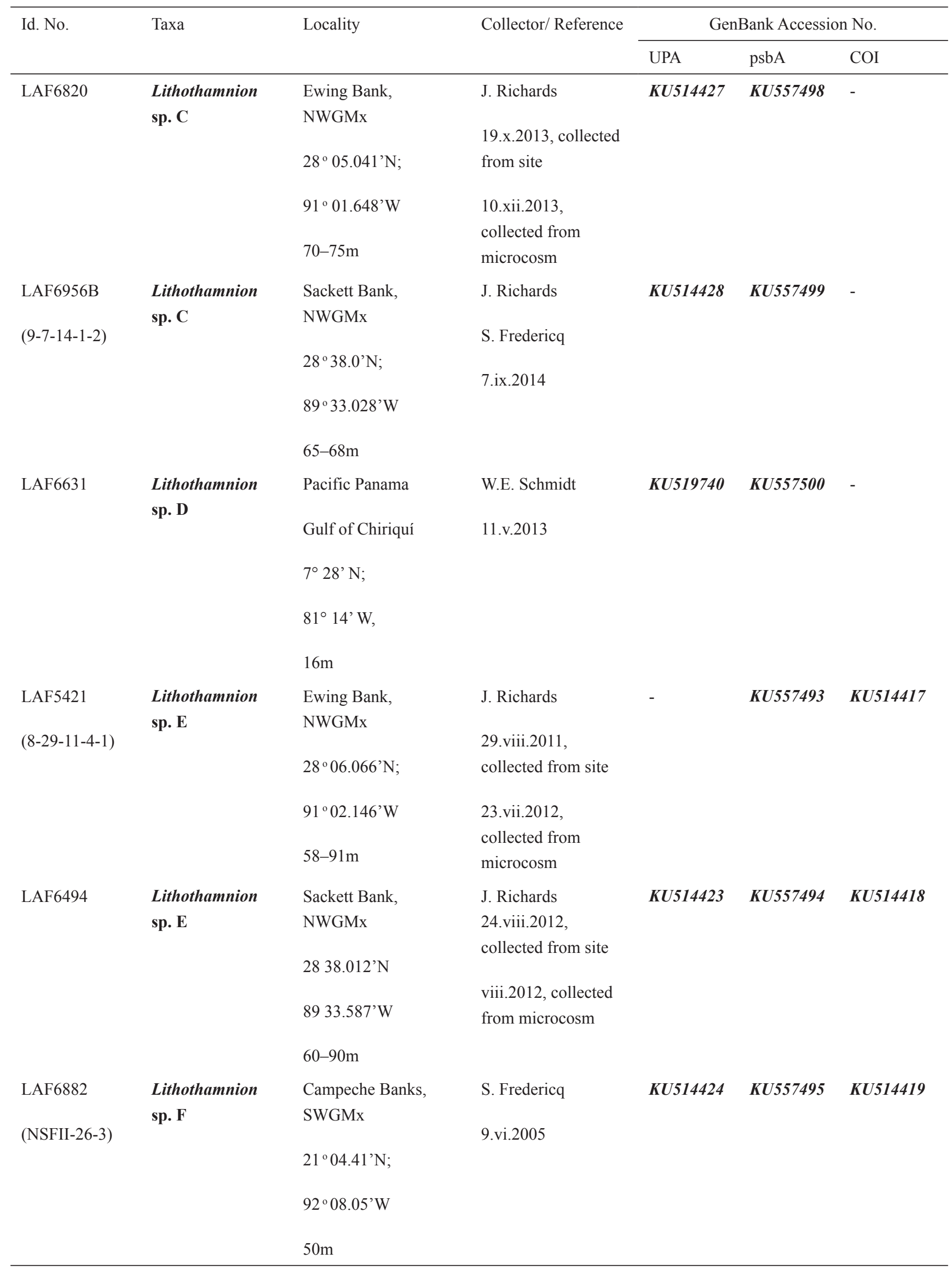

...Continued on next page 
TABLE 1. (Continued)

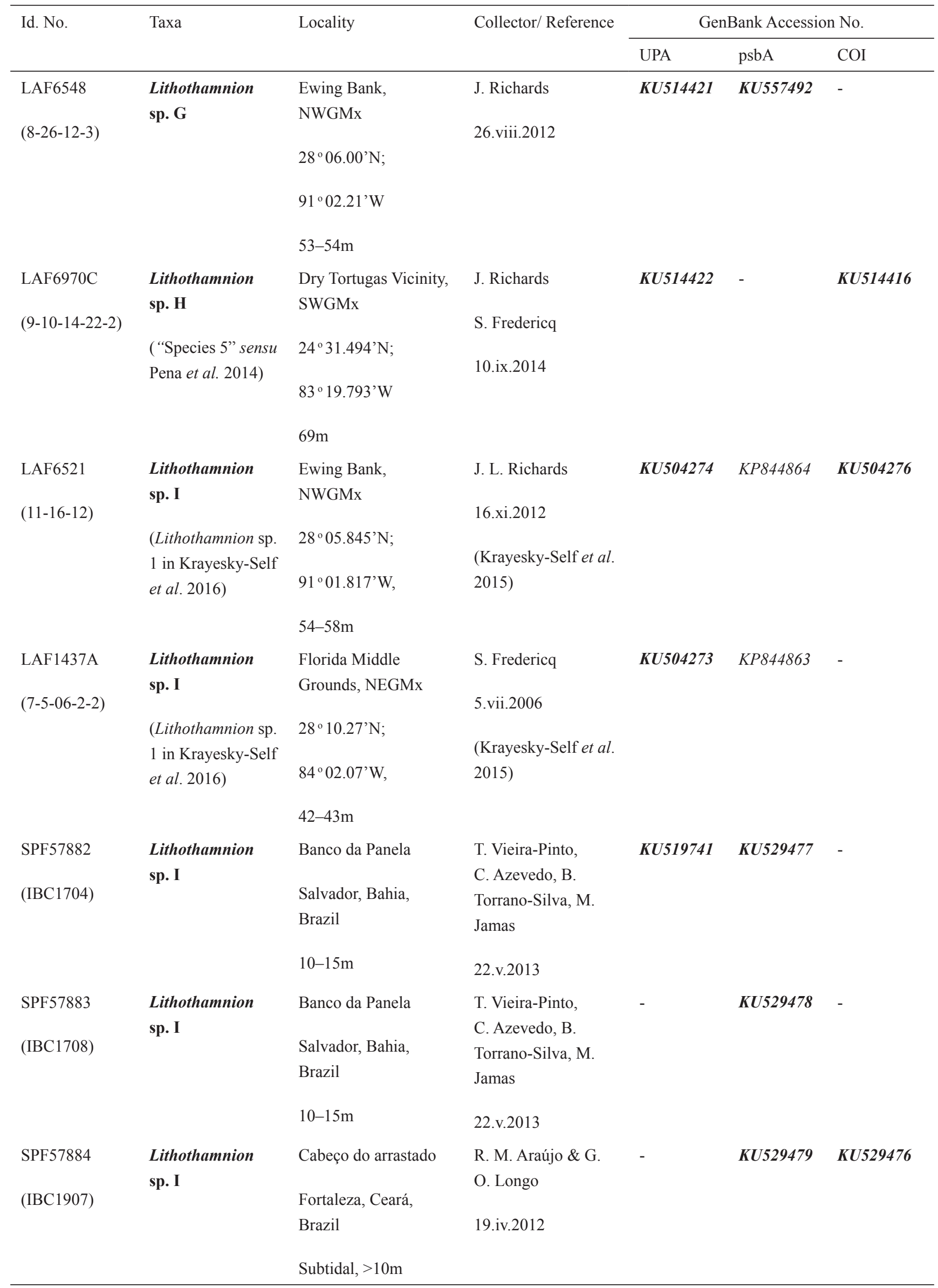

...Continued on next page 
TABLE 1. (Continued)

\begin{tabular}{|c|c|c|c|c|c|c|}
\hline \multirow[t]{2}{*}{ Id. No. } & \multirow[t]{2}{*}{ Taxa } & \multirow[t]{2}{*}{ Locality } & \multirow[t]{2}{*}{ Collector/ Reference } & \multicolumn{3}{|c|}{ GenBank Accession No. } \\
\hline & & & & UPA & $\mathrm{psbA}$ & $\mathrm{COI}$ \\
\hline PHYKOS7249 & $\begin{array}{l}\text { Lithothamnion } \\
\text { sp. J } \\
\text { (Lithothamnion sp. } \\
2 \text { in Krayesky-Self } \\
\text { et al. 2016) }\end{array}$ & $\begin{array}{l}\text { Pacific Panama } \\
7^{\circ} 28^{\prime} \mathrm{N} \\
81^{\circ} 14^{\prime} \mathrm{W} \\
16 \mathrm{~m}\end{array}$ & $\begin{array}{l}\text { W. E. Schmidt } \\
\text { 11.v.2013 } \\
\text { (Krayesky-Self et al. } \\
2015 \text { ) }\end{array}$ & KU504275 & KP844865 & KU504277 \\
\hline NCU 588631 & $\begin{array}{l}\text { Callilithophytum } \\
\text { parcum }\end{array}$ & Washington, U.S.A. & Adey et al. 2015 & - & KP142742 & - \\
\hline US 169083 & $\begin{array}{l}\text { Clathromorphum } \\
\text { circumscriptum }\end{array}$ & Labrador, Canada & Adey et al. 2015 & - & KP142731 & - \\
\hline US 170929 & $\begin{array}{l}\text { Clathromorphum } \\
\text { compactum }\end{array}$ & Labrador, Canada & Adey et al. 2015 & - & KP142730 & - \\
\hline US 170930 & $\begin{array}{l}\text { Clathromorphum } \\
\text { compactum }\end{array}$ & $\begin{array}{l}\text { Newfoundland } \\
\text { Canada }\end{array}$ & Adey et al. 2015 & - & KP142729 & - \\
\hline NCU 601308 & $\begin{array}{l}\text { Clathromorphum } \\
\text { compactum }\end{array}$ & Maine, U.S.A. & Adey et al. 2015 & - & KP142757 & - \\
\hline NCU 627718 & $\begin{array}{l}\text { Clathromorphum } \\
\text { nereostratum }\end{array}$ & $\begin{array}{l}\text { Commander Islands, } \\
\text { Russia }\end{array}$ & Adey et al. 2015 & - & KP142758 & - \\
\hline NCU 597128 & $\begin{array}{l}\text { Clathromorphum } \\
\text { nereostratum }\end{array}$ & Alaska, U.S.A. & Adey et al. 2015 & - & KP142759 & - \\
\hline US 170931 & $\begin{array}{l}\text { Clathromorphum } \\
\text { nereostratum }\end{array}$ & Alaska, U.S.A. & Adey et al. 2015 & - & KP142733 & - \\
\hline NCU 627106 & $\begin{array}{l}\text { Clathromorphum } \\
\text { nereostratum }\end{array}$ & Alaska, U.S.A. & Adey et al. 2015 & - & KP142760 & - \\
\hline NCU 627110 & $\begin{array}{l}\text { Clathromorphum } \\
\text { nereostratum }\end{array}$ & Alaska, U.S.A. & Adey et al. 2015 & - & KP142761 & - \\
\hline NCU 597127 & $\begin{array}{l}\text { Heydrichia } \\
\text { woelkerlingii }\end{array}$ & $\begin{array}{l}\text { Cape Province, South } \\
\text { Africa }\end{array}$ & $\begin{array}{l}\text { Mateo-Cid et al. } \\
\text { 2014b }\end{array}$ & - & JQ917415 & - \\
\hline US 169189 & $\begin{array}{l}\text { "Leptophytum" } \\
\text { foecundum }\end{array}$ & Labrador, Canada & Adey et al. 2015 & - & KP142726 & - \\
\hline US 169242 & Leptophytum laeve & Labrador, Canada & Adey et al. 2015 & - & KP142735 & - \\
\hline FRA1993 & $\begin{array}{l}\text { Lithothamnion } \mathrm{cf} . \\
\text { ruptile }\end{array}$ & Guadeloupe, F.W.I. & Peña et al. 2014 & - & KJ710353 & - \\
\hline GALW15750 & $\begin{array}{l}\text { Lithothamnion } \\
\text { corallioides }\end{array}$ & $\begin{array}{l}\text { Bay of Brest, France } \\
6.2 \mathrm{~m}\end{array}$ & $\begin{array}{l}\text { Hernández-Kantún } \\
\text { et al. } 2014\end{array}$ & - & JQ896234 & - \\
\hline CPVP-563 & $\begin{array}{l}\text { Lithothamnion } \\
\text { corallioides }\end{array}$ & Galicia, Spain & Pardo et al. 2014 & - & KC819256 & KC861460 \\
\hline CPVP-691 & $\begin{array}{l}\text { Lithothamnion } \\
\text { corallioides }\end{array}$ & Galicia, Spain & Pardo et al. 2014 & - & KC819261 & *KC861467 \\
\hline
\end{tabular}

...Continued on next page 
TABLE 1. (Continued)

\begin{tabular}{|c|c|c|c|c|c|c|}
\hline \multirow[t]{2}{*}{ Id. No. } & \multirow[t]{2}{*}{ Taxa } & \multirow[t]{2}{*}{ Locality } & \multirow[t]{2}{*}{ Collector/ Reference } & \multicolumn{3}{|c|}{ GenBank Accession No. } \\
\hline & & & & UPA & $\mathrm{psbA}$ & $\mathrm{COI}$ \\
\hline CPVP-802 & $\begin{array}{l}\text { Lithothamnion } \\
\text { corallioides }\end{array}$ & Galicia, Spain & Pardo et al. 2014 & - & - & KC861447 \\
\hline CPVP-808 & $\begin{array}{l}\text { Lithothamnion } \\
\text { corallioides }\end{array}$ & Brittany, France & Pardo et al. 2014 & - & KC819264 & *KC861452 \\
\hline CPVP-817 & $\begin{array}{l}\text { Lithothamnion } \\
\text { corallioides }\end{array}$ & Brittany, France & Pardo et al. 2014 & - & KC819265 & KC861448 \\
\hline CPVP-1167 & $\begin{array}{l}\text { Lithothamnion } \\
\text { corallioides }\end{array}$ & $\begin{array}{l}\text { Wales, United } \\
\text { Kingdom }\end{array}$ & Pardo et al. 2014 & - & - & KC861487 \\
\hline NZC2315 & $\begin{array}{l}\text { Lithothamnion } \\
\text { crispatum }\end{array}$ & $\begin{array}{l}\text { North Island, New } \\
\text { Zealand }\end{array}$ & Nelson et al. 2015 & - & FJ361502 & - \\
\hline RHO2099 & $\begin{array}{l}\text { Lithothamnion } \\
\text { crispatum }\end{array}$ & $\begin{array}{l}\text { North Island New } \\
\text { Zealand }\end{array}$ & Unpublished & - & KC963420 & - \\
\hline VPF00148 & $\begin{array}{l}\text { Lithothamnion } \mathrm{cf} \text {. } \\
\text { crispatum }\end{array}$ & $\begin{array}{l}\text { Mediterranean Sea, } \\
\text { Spain }\end{array}$ & Peña et al. 2014 & - & KJ710356 & - \\
\hline US 170935 & $\begin{array}{l}\text { Lithothamnion } \\
\text { glaciale }\end{array}$ & Quebec, Canada & Adey et al. 2015 & - & KP142721 & - \\
\hline US 170936 & $\begin{array}{l}\text { Lithothamnion } \\
\text { glaciale }\end{array}$ & $\begin{array}{l}\text { Newfoundland, } \\
\text { Canada }\end{array}$ & Adey et al. 2015 & - & KP142722 & - \\
\hline GWS007542 & $\begin{array}{l}\text { Lithothamnion } \\
\text { glaciale }\end{array}$ & $\begin{array}{l}\text { Newfoundland and } \\
\text { Labrador, Canada }\end{array}$ & $\begin{array}{l}\text { Hind \& Saunders } \\
2013\end{array}$ & - & JQ422235 & HM918812 \\
\hline GALW15742 & $\begin{array}{l}\text { Lithothamnion } \\
\text { glaciale }\end{array}$ & $\begin{array}{l}\text { Kingstown Bay, } \\
\text { Ireland }\end{array}$ & $\begin{array}{l}\text { Hernández-Kantún } \\
\text { et al. } 2014\end{array}$ & - & JQ896233 & - \\
\hline CPVP-91 & $\begin{array}{l}\text { Lithothamnion } \\
\text { glaciale }\end{array}$ & Skarsundet, Norway & Pardo et al. 2014 & - & KC819244 & *KC861508 \\
\hline CPVP-93 & $\begin{array}{l}\text { Lithothamnion } \\
\text { glaciale }\end{array}$ & Skarsundet, Norway & Pardo et al. 2014 & - & - & KC861503 \\
\hline CPVP-1401 & $\begin{array}{l}\text { Lithothamnion } \\
\text { glaciale }\end{array}$ & Norway & Pardo et al. 2014 & - & - & KC861504 \\
\hline CPVP-1443 & $\begin{array}{l}\text { Lithothamnion } \\
\text { glaciale }\end{array}$ & Norway & Pardo et al. 2014 & - & KC819270 & KC861507 \\
\hline CPVP-1444 & $\begin{array}{l}\text { Lithothamnion } \\
\text { glaciale }\end{array}$ & Norway & Pardo et al. 2014 & - & KC819271 & * KC861509 \\
\hline GWS007542 & $\begin{array}{l}\text { Lithothamnion } \\
\text { glaciale }\end{array}$ & $\begin{array}{l}\text { Newfoundland and } \\
\text { Labrador, Canada }\end{array}$ & Unpublished & - & - & HM918812 \\
\hline US 170936 & $\begin{array}{l}\text { Lithothamnion } \\
\text { glaciale }\end{array}$ & $\begin{array}{l}\text { Newfoundland, } \\
\text { Canada }\end{array}$ & Adey et al. 2015 & - & KP142722 & - \\
\hline US 169116 & $\begin{array}{l}\text { Lithothamnion } \\
\text { lemoineae }\end{array}$ & Labrador, Canada & Adey et al. 2015 & - & KP142723 & - \\
\hline US 170937 & $\begin{array}{l}\text { Lithothamnion } \\
\text { lemoineae }\end{array}$ & Labrador, Canada & Adey et al. 2015 & - & KP142724 & - \\
\hline
\end{tabular}

...Continued on next page 
TABLE 1. (Continued)

\begin{tabular}{|c|c|c|c|c|c|c|}
\hline \multirow[t]{2}{*}{ Id. No. } & \multirow[t]{2}{*}{ Taxa } & \multirow[t]{2}{*}{ Locality } & \multirow[t]{2}{*}{ Collector/ Reference } & \multicolumn{3}{|c|}{ GenBank Accession No. } \\
\hline & & & & UPA & $\mathrm{psbA}$ & $\mathrm{COI}$ \\
\hline US 169317 & $\begin{array}{l}\text { Lithothamnion } \\
\text { lemoineae }\end{array}$ & $\begin{array}{l}\text { Newfoundland, } \\
\text { Canada }\end{array}$ & Adey et al. 2015 & - & KP142725 & - \\
\hline GALW15734 & $\begin{array}{l}\text { Lithothamnion } \\
\text { muelleri }\end{array}$ & $\begin{array}{l}\text { Baja California Sur, } \\
\text { Mexico }\end{array}$ & $\begin{array}{l}\text { Hernández-Kantún } \\
\text { et al. } 2014\end{array}$ & - & $J Q 896241$ & - \\
\hline LBC0642 & Lithothamnion sp. & Fiji & Bittner et al. 2011 & - & $G Q 917461$ & GQ917270 \\
\hline LBC0845 & Lithothamnion sp. & New Caledonia & Bittner et al. 2011 & - & $G Q 917490$ & GQ917298 \\
\hline CPVP30 & Lithothamnion sp. & Hvalfjoerdur, Iceland & Pardo et al. 2014 & - & - & KC861510 \\
\hline CPVP92 & $\begin{array}{l}\text { Lithothamnion } \\
\text { sp. } 2\end{array}$ & Skarsundet, Norway & Pardo et al. 2014 & - & KC819245 & KC861512 \\
\hline CPVP305 & $\begin{array}{l}\text { Lithothamnion } \\
\text { sp. } 2\end{array}$ & Scotland, UK & Pardo et al. 2014 & - & KC819248 & *KC861517 \\
\hline $\begin{array}{l}\text { FRA1148 } \\
\text { PC0144033 }\end{array}$ & $\begin{array}{l}\text { Lithothamnion } \\
\text { sp. } 1 \\
\text { "Species 1" }\end{array}$ & Guadeloupe, F.W.I. & Peña et al. 2014 & - & KJ710352 & KJ710343 \\
\hline $\begin{array}{l}\text { FRA1152 } \\
\text { PC0144055 }\end{array}$ & $\begin{array}{l}\text { Lithothamnion } \\
\text { sp. } 1 \\
\text { "Species 1" }\end{array}$ & Guadeloupe, F.W.I. & Peña et al. 2014 & - & - & KJ710342 \\
\hline $\begin{array}{l}\text { FRA1059 } \\
\text { PC0142655 }\end{array}$ & $\begin{array}{l}\text { Lithothamnion } \\
\text { sp. } 1 \\
\text { "Species 1" }\end{array}$ & Guadeloupe, F.W.I. & Peña et al. 2014 & - & - & KJ710345 \\
\hline $\begin{array}{l}\text { FRA2172 } \\
\text { PC0144249 }\end{array}$ & $\begin{array}{l}\text { Lithothamnion } \\
\text { sp. } 2 \\
\text { "Species 2" }\end{array}$ & Guadeloupe, F.W.I. & Peña et al. 2014 & - & KJ710354 & KJ710344 \\
\hline $\begin{array}{l}\text { FRA1211 } \\
\text { PC0144042 }\end{array}$ & $\begin{array}{l}\text { Lithothamnion } \\
\text { sp. } 3 \\
\text { "Species 3" }\end{array}$ & Guadeloupe, F.W.I. & Peña et al. 2014 & - & KJ710355 & KJ710346 \\
\hline $\begin{array}{l}\text { FRA2164 } \\
\text { PC0144248 }\end{array}$ & $\begin{array}{l}\text { Lithothamnion } \\
\text { sp. } 4 \\
\text { "Species 4" }\end{array}$ & Guadeloupe, F.W.I. & Peña et al. 2014 & - & - & KJ710341 \\
\hline $\begin{array}{l}\text { FRA2 } 177 \\
\text { PC0144250 }\end{array}$ & $\begin{array}{l}\text { Lithothamnion } \\
\text { sp. } 5 \\
\text { "Species 5" }\end{array}$ & Guadeloupe, F.W.I. & Peña et al. 2014 & - & KJ710349 & KJ710337 \\
\hline GWS020939 & $\begin{array}{l}\text { Lithothamnion sp. } \\
\text { 32BC }\end{array}$ & $\begin{array}{l}\text { British Columbia, } \\
\text { Canada }\end{array}$ & Saunders 2014 & - & - & KM254875 \\
\hline US 170938 & $\begin{array}{l}\text { Lithothamnion } \\
\text { tophiforme }\end{array}$ & Labrador, Canada & Adey et al. 2015 & - & KP142720 & - \\
\hline
\end{tabular}


TABLE 1. (Continued)

\begin{tabular}{|c|c|c|c|c|c|c|}
\hline \multirow[t]{2}{*}{ Id. No. } & \multirow[t]{2}{*}{ Taxa } & \multirow[t]{2}{*}{ Locality } & \multirow[t]{2}{*}{ Collector/ Reference } & \multicolumn{3}{|c|}{ GenBank Accession No. } \\
\hline & & & & UPA & $\mathrm{psbA}$ & $\mathrm{COI}$ \\
\hline ARS02826 & $\begin{array}{l}\text { Mesophyllum } \\
\text { erubescens }\end{array}$ & Hawaii & Sherwood et al. 2010 & $H Q 420974$ & - & $H Q 422718$ \\
\hline ARS02835 & $\begin{array}{l}\text { Mesophyllum } \\
\text { erubescens }\end{array}$ & Hawaii & Sherwood et al. 2010 & $H Q 420979$ & - & $H Q 422717$ \\
\hline FLOR 14900 & $\begin{array}{l}\text { Mesophyllum } \\
\text { erubescens }\end{array}$ & ES, Brazil & Sissini et al. 2014 & KM877275 & KM983038 & - \\
\hline FLOR 14901 & $\begin{array}{l}\text { Mesophyllum } \\
\text { erubescens }\end{array}$ & ES, Brazil & Sissini et al. 2014 & KM877276 & KM983039 & - \\
\hline US 170940 & $\begin{array}{l}\text { Mesophyllum } \\
\text { lichenoides }\end{array}$ & Spain & Adey et al. 2015 & - & KP142728 & - \\
\hline LBC0031 & $\begin{array}{l}\text { Mesophyllum } \\
\text { lichenoides }\end{array}$ & France & Bittner et al. 2011 & - & GQ917439 & GQ917249 \\
\hline GALW15775 & $\begin{array}{l}\text { Mesophyllum } \\
\text { lichenoides }\end{array}$ & $\begin{array}{l}\text { Kingstown Bay, } \\
\text { Ireland }\end{array}$ & $\begin{array}{l}\text { Hernández-Kantún } \\
\text { et al. } 2014\end{array}$ & - & $J Q 896244$ & - \\
\hline CPVP-464 & Mesophyllum sp. 1 & Algarve, Portugal & Pardo et al. 2014 & - & KC819252 & KC861519 \\
\hline CPVP-467 & Mesophyllum sp. 1 & Algarve, Portugal & Pardo et al. 2014 & - & - & KC861521 \\
\hline CPVP-514 & Mesophyllum sp. 1 & Algarve, Portugal & Pardo et al. 2014 & - & - & KC861518 \\
\hline CPVP-1157 & Mesophyllum sp. 2 & Canary Islands, Spain & Pardo et al. 2014 & - & KC819269 & KC861522 \\
\hline CPVP-307 & Mesophyllum sp. 2 & Canary Islands, Spain & Pardo et al. 2014 & - & KC819249 & KC861523 \\
\hline CPVP-776 & $\begin{array}{l}\text { Mesophyllum } \\
\text { sphaericum }\end{array}$ & Galacia, Spain & Pardo et al. 2014 & - & KC819262 & KC861526 \\
\hline AM-C-20 & $\begin{array}{l}\text { Neopolyporolithon } \\
\text { loculosum }\end{array}$ & Alaska, USA & Adey et al. 2015 & - & KP142737 & - \\
\hline AM-IP-I & $\begin{array}{l}\text { Neopolyporolithon } \\
\text { loculosum }\end{array}$ & Alaska, USA & Adey et al. 2015 & - & KP142738 & - \\
\hline AM-SM-I & $\begin{array}{l}\text { Neopolyporolithon } \\
\text { loculosum }\end{array}$ & Alaska, USA & Adey et al. 2015 & - & KP142750 & - \\
\hline NCU 588641 & $\begin{array}{l}\text { Neopolyporolithon } \\
\text { reclinatum }\end{array}$ & Washington, USA & Adey et al. 2015 & - & KP142743 & - \\
\hline BM000712373 & $\begin{array}{l}\text { Phymatolithon } \\
\text { calcareum }\end{array}$ & Cornwall, UK & $\begin{array}{l}\text { Pardo et al. } 2014, \\
\text { Peña et al. } 2014 \mathrm{a}\end{array}$ & - & $J Q 896231$ & $K F 808323$ \\
\hline US 170885 & $\begin{array}{l}\text { Phymatolithon } \\
\text { lenormandii }\end{array}$ & Nova Scotia & Adey et al. 2015 & - & KP142718 & - \\
\hline ARS02350 & Phymatolithon sp. & Hawaii, USA & Sherwood et al. 2010 & HQ421548 & - & - \\
\hline USAJ-A-73233 & $\begin{array}{l}\text { Sporolithon } \\
\text { episporum }\end{array}$ & Atlantic Costa Rica & Bahia et al. 2014 & - & KC870925 & - \\
\hline ARS02819 & $\begin{array}{l}\text { Sporolithon } \\
\text { ptychoides }\end{array}$ & Hawaii, USA & Sherwood et al. 2010 & $H Q 420971$ & - & $H Q 422711$ \\
\hline GM AF5 & Sporolithon sp. & Bahia, Brazil & Adey et al. 2015 & - & KP142752 & - \\
\hline LBC0567 & Sporolithon sp. & Vanuatu & Bittner et al. 2011 & - & $G Q 917500$ & GQ917259 \\
\hline
\end{tabular}


TABLE 1. (Continued)

\begin{tabular}{|c|c|c|c|c|c|c|}
\hline \multirow[t]{2}{*}{ Id. No. } & \multirow[t]{2}{*}{ Taxa } & \multirow[t]{2}{*}{ Locality } & \multirow[t]{2}{*}{ Collector/ Reference } & \multicolumn{3}{|c|}{ GenBank Accession No. } \\
\hline & & & & UPA & $\mathrm{psbA}$ & $\mathrm{COI}$ \\
\hline LBC0695 & Sporolithon sp. & Fiji & Bittner et al. 2011 & - & $G Q 917501$ & $G Q 917279$ \\
\hline IBC 1519 & Sporolithon sp. 1 & Paraíba, Brazil & $\begin{array}{l}\text { Vieira-Pinto et al. } \\
2014\end{array}$ & KP192382 & - & - \\
\hline LLG0081 & $\begin{array}{l}\text { Synarthrophyton } \\
\text { patena }\end{array}$ & Australia & Bittner et al. 2011 & - & GQ917499 & GQ917304 \\
\hline $\begin{array}{l}\text { DH20 } \\
\text { (LTB17962) }\end{array}$ & $\begin{array}{l}\text { Synarthrophyton } \\
\text { patena }\end{array}$ & Australia & Nelson et al. 2015 & - & KM369060 & - \\
\hline NZC0899 & $\begin{array}{l}\text { Synarthrophyton } \\
\text { patena }\end{array}$ & $\begin{array}{l}\text { North Island, New } \\
\text { Zealand }\end{array}$ & Nelson et al. 2015 & - & DQ168000 & - \\
\hline LBC0640 & $\begin{array}{l}\text { Unidentified } \\
\text { Hapalidiaceae }\end{array}$ & New Caledonia & Bittner et al. 2011 & - & GQ917460 & GQ917269 \\
\hline $\begin{array}{l}\text { GALW } 15736 \\
\text { (E58) }\end{array}$ & $\begin{array}{l}\text { Unidentified } \\
\text { Hapalidiaceae }\end{array}$ & $\begin{array}{l}\text { Baja California Sur, } \\
\text { Mexico }\end{array}$ & $\begin{array}{l}\text { Hernández-Kantún } \\
\text { et al. } 2014\end{array}$ & - & $J Q 896242$ & - \\
\hline FLOR 14925 & $\begin{array}{l}\text { Unidentified } \\
\text { Hapalidiaceae }\end{array}$ & Ceará, Brazil & Sissini et al. 2014 & KM877299 & - & - \\
\hline FLOR 14926 & $\begin{array}{l}\text { Unidentified } \\
\text { Hapalidiaceae }\end{array}$ & Santa Catarina, Brazil & Sissini et al. 2014 & KM877300 & - & - \\
\hline FLOR 14927 & $\begin{array}{l}\text { Unidentified } \\
\text { Hapalidiaceae }\end{array}$ & Rio de Janeiro, Brazil & Sissini et al. 2014 & KM877301 & - & - \\
\hline FLOR 14928 & $\begin{array}{l}\text { Unidentified } \\
\text { Hapalidiaceae }\end{array}$ & Santa Catarina, Brazil & Sissini et al. 2014 & KM877302 & - & - \\
\hline FLOR 14929 & $\begin{array}{l}\text { Unidentified } \\
\text { Hapalidiaceae }\end{array}$ & Santa Catarina, Brazil & Sissini et al. 2014 & KM877303 & - & - \\
\hline FLOR 14930 & $\begin{array}{l}\text { Unidentified } \\
\text { Hapalidiaceae }\end{array}$ & Paraíba, Brazil & Sissini et al. 2014 & KM877304 & - & - \\
\hline
\end{tabular}

DNA Extraction and PCR protocols. Total genomic DNA was extracted from samples from the GMx and Panama as in Richards et al. (2014), while Brazilian samples were extracted as in Vieira-Pinto et al. (2014). In all cases DNA was extracted from the same specimens used for morphological analysis. Overall, 17 specimens of Lithothamnion spp. were sequenced (Table 1).

Three markers were selected for PCR: the chloroplast-encoded photosystem II reaction center protein D1 gene ( $p s b \mathrm{~A}$ ) and Universal Plastid Amplicon 23S rRNA gene (UPA), and the mitochondrion-encoded cytochrome oxidase subunit I gene (COI). PCR for $p s b$ A was performed using the primers referenced in Yoon et al. (2002) under the following thermal profile: an initial denaturation at $94^{\circ} \mathrm{C}$ for $3 \mathrm{~min}$ followed by 39 cycles at $94^{\circ} \mathrm{C}$ for $30 \mathrm{sec}$ (denaturation), $52^{\circ} \mathrm{C}$ for $50 \mathrm{sec}$ (primer annealing), and $72^{\circ} \mathrm{C}$ (extension) for $1 \mathrm{~min}$ followed by a final extension at $72^{\circ} \mathrm{C}$ for $5 \mathrm{~min}$. PCR for COI was conducted using the primers referenced in Saunders (2005) with an initial denaturation at $94^{\circ} \mathrm{C}$ followed by 40 cycles at $94^{\circ} \mathrm{C}$ for $1 \mathrm{~min}$ (denaturation), $45^{\circ} \mathrm{C}$ for $1 \mathrm{~min}$ (primer annealing), and $72^{\circ} \mathrm{C}$ (extension) for $1 \mathrm{~min}$ followed by a final extension at $72^{\circ} \mathrm{C}$ for $5 \mathrm{~min}$. PCR for UPA was performed using the primers and PCR protocol referenced in Sherwood \& Presting (2007). PCR products where purified with ExoSAP-IT® (USB $\left.{ }^{\circledR}\right)$ or by excision on a Agarose II (Ameresco) TAE (Tris-acetate-EDTA) gel followed by digestion with GELase ${ }^{\mathrm{TM}}$ (Epicentre $\left.{ }^{\circledR}\right)$. Purified PCR products were subsequently cycle sequenced using the BigDye Terminator v 3.1 kit (Life Technologies). Resulting cycle sequence reactions were purified with ETOH/EDTA precipitation and were either sequenced in-house at the UL Lafayette campus on an ABI Model 3130xl Genetic Analyzer, at the University of São Paulo campus on an ABI Model 
3730 Genetic Analyzer, or outsourced (Beckman Coulter Genomics Danvers, MA). Resulting chromatograms were assembled using Sequencher 5.1 (Gene Codes Corp., Ann Arbor, MI, USA).

Single gene Alignment. Alignments were constructed including newly generated and previously available DNA sequences from GenBank (Table 1) using the CLUSTAL W (Thompson et al. 1994) program in MEGA 5.2.2 (Tamura et al. 2011). For UPA, a small ambiguous region was cropped to the nearest conserved region, and the alignment was truncated to minimize missing data at the 3 ' end. The final UPA alignment was 352 base pairs (bp) in length and included 14 newly generated sequences, 12 publicly available sequences (i.e. downloaded from GenBank), and two sequences of Sporolithon Heydrich served as the outgroup. PsbA and COI aligned unambiguously. The final psbA alignment ( $863 \mathrm{bp}$ ) comprised 13 newly generated sequences, 62 downloaded sequences and three sequences of the Sporolithales as the outgroup. The final COI alignment ( $652 \mathrm{bp}$ ) included eight newly generated sequences, 33 downloaded sequences, and three sequences of Sporolithon as the outgroup.

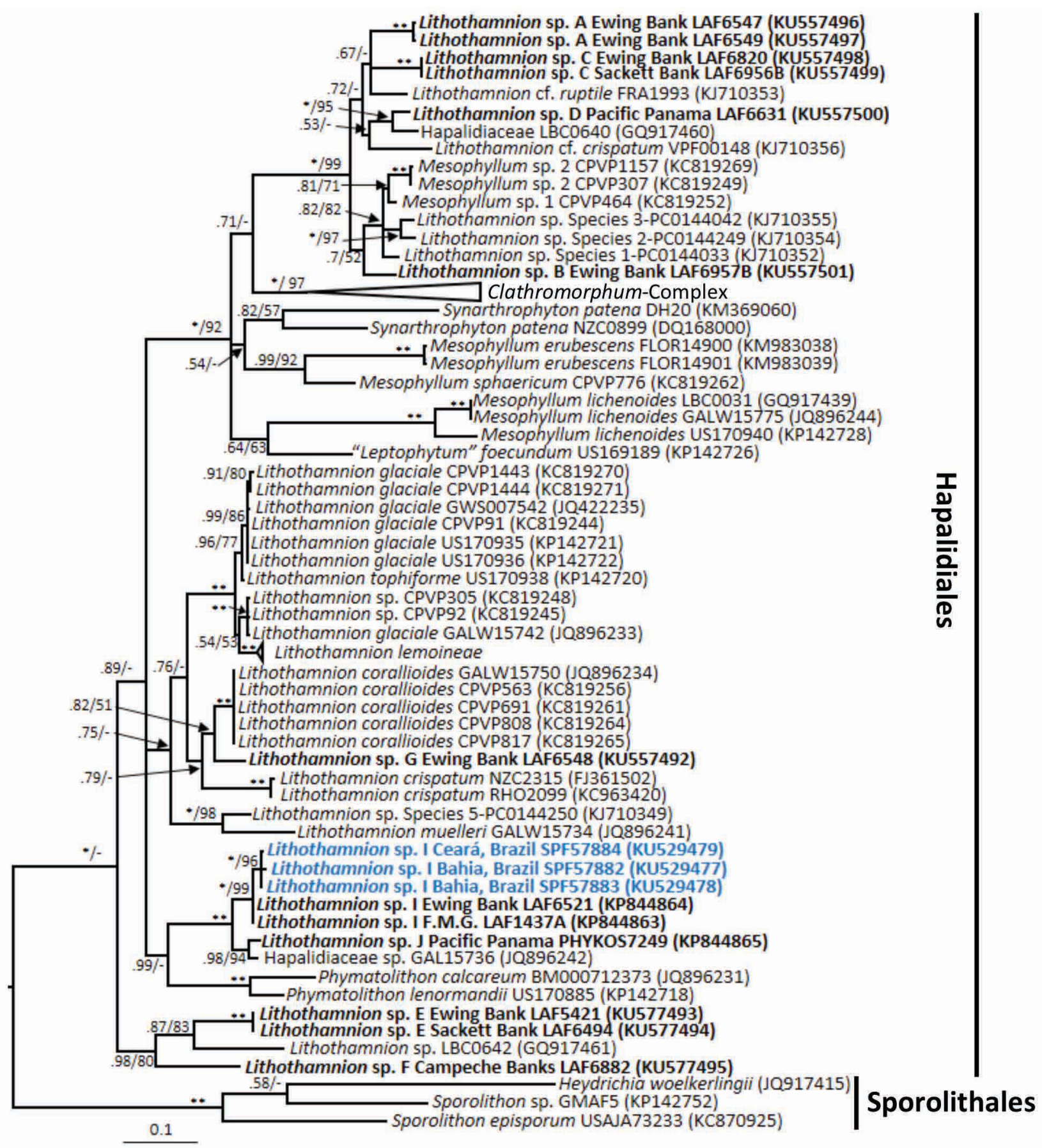

FIGURE 1. Phylogeny based on Bayesian analysis of $p s b$ A. Node values indicate posterior probability (left) and bootstrap values for ML analyses out of 1,000 replicates (right), * indicates full support. Newly generated sequences shown in bold. 
Multi-gene Alignment. UPA, psbA, and COI alignments were imported to MacClade 4.08 (Maddison \& Maddison 2000) and blank cells were added for each gene where data for a specimen was missing. Alignments were exported as NEXUS files and concatenated using the application Sequence Matrix 1.7.8 (Vaidya et al. 2011). The final concatenated alignment (1,867 base-pairs) was exported as a PHYLIP file for analysis with RAxML and included 60 sequences in the ingroup and three sequences of Sporolithon as the outgroup (shown in italics in Table 1).

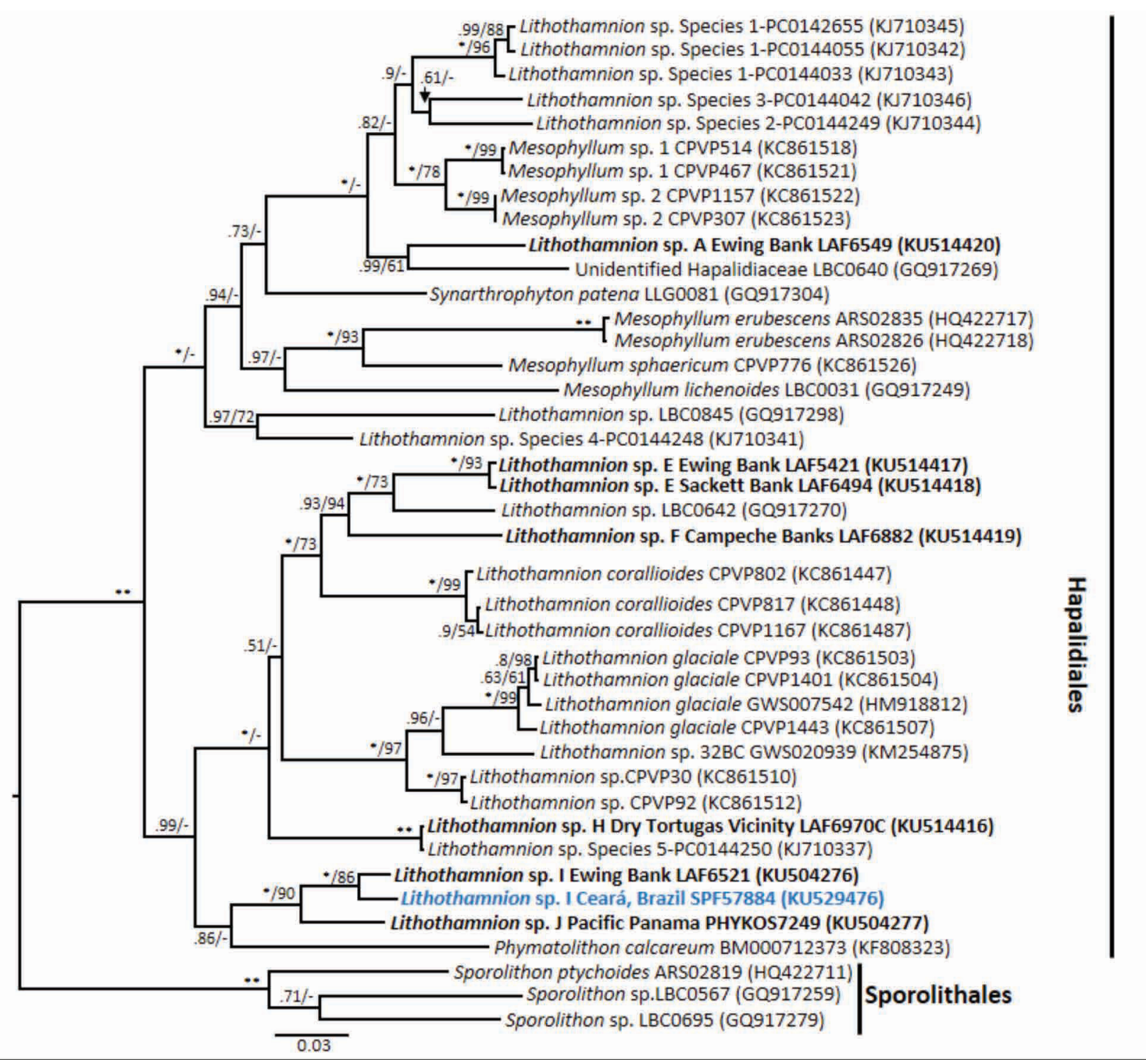

FIGURE 2. Phylogeny based on Bayesian analysis of COI. Node values indicate posterior probability (left) and bootstrap values for ML analyses out of 1,000 replicates (right), * indicates full support. Newly generated sequences shown in bold.

Phylogenetic Analyses. ML analyses for the UPA, $p s b \mathrm{~A}, \mathrm{COI}$, and the concatenated alignments were conducted with the RAxML-HPC2 program using the online server 'The CIPRES Science Gateway V. 3.3' (Miller et al. 2010) with a GTR $+\mathrm{I}+\mathrm{G}$ model of evolution partitioned per codon position (and partitioned per gene for the multi-gene alignment) 1,000 topological searches from random restarts, and 1,000 bootstrap replicates to assess branch support. Bayesian analyses (BI) of the psbA and COI alignments were conducted using Mr. Bayes 3.2.6 (Ronquist et al. 2012) with a $\mathrm{GTR}+\mathrm{I}+\mathrm{G}$ model of evolution partitioned per codon position. Two parallel analyses were conducted, each consisting of four MCMC chains ( 3 heated and $1 \mathrm{cool}$ ) with $5 \times 10^{6}$ generations. Resampling was performed every 1,000 generations resulting in a total of 10,002 trees for both runs. The first $10 \%$ of each run was discarded as "burn-in", and a consensus tree was built with remaining data. Convergence was determined with Tracer v1.6 (Rambaut et al. 2014).

Species Delimitation Analyses. Species delimitation analyses were performed on each of the $p s b$ A and COI datasets with both Automatic Barcode Gap Species Discovery (ABGD) and General Mixed Yule Coalescence (GMYC). For $\mathrm{ABGD}$, branch lengths were extracted from the $p s b \mathrm{~A}$ and COI RAxML trees with the function cophenetic.phylo of the package APE in R (Paradis et al. 2004, R Core Team, 2015) to produce a distance matrix as input. The latter was run with 
minimum (pmin) and maximum (pmax) intraspecific distance priors comprised between 0.001 and 1 in 100 steps, and with a relative gap width values of 0.003 . Alternative species boundaries hypotheses were produced with the (GMYC) model with the package SPLITS in R (Fujisawa \& Barraclough 2013), with the single threshold method based on an ultrametric tree generated in BEAST v2.0 (Bouckaert et al. 2014) using a relaxed log-normal clock with a constant population coalescent as prior, and a GTR $+\mathrm{I}+\mathrm{G}$ model of evolution partitioned per codon position. MCMC chains were run for 100 million generations (sampled every 1000th generations) and the quality of the run assessed in Tracer v1.6 (Rambaut \& Drummond 2007) to ensure that ESS values were $>200$ with the default burnin (10,000 trees).

Evaluation of Pairwise Distance Distribution for Three Markers. The distribution of raw pairwise distances (i.e. divergence) was computed for the three markers utilized in the present study in order to evaluate their phylogenetic informativeness. Distances were calculated in R (R Core Team 2014) by dividing the number of base pair differences by the alignment length. Alignments were cropped at their 5' and 3' ends when missing data was present and short sequences were removed as to not overinflate pairwise distances.

Scanning Electron Microscopy. Portions of the thallus from silica gel-dried specimens were removed using a razor blade and forceps. Crustose specimens were sectioned by performing vertical fractures (cutting from thallus surface to substratum) whereas protuberances were sectioned longitudinally (through the middle of the protuberance from tip to base) and transversely (through the lateral sides of protuberance). Specimens were sectioned manually using a new single edge razor blade for each fracture and were mounted using liquid graphite and coated with $15 \mathrm{~nm}$ of gold. To ensure even distribution of the gold over the three dimensional features in the sections, coating was performed in two applications. First, $8 \mathrm{~nm}$ of gold was applied with the stub lying flat on the stage of the coating chamber. After the first application, the specimen was tilted using a coin placed underneath the stub and a second application of $7 \mathrm{~nm}$ of gold was performed. Specimens were viewed using a Hitachi S-3000N scanning electron microscope (SEM) at a voltage of $15 \mathrm{kV}$, housed in the Microscopy Center at UL Lafayette, following the manufacturer's instructions. Cell dimensions were measured from SEM micrographs following the protocols of Irvine and Chamberlain (1994) and Adey et al. (2005). Terminology follows Woelkerling (1988) and Adey et al. (2015).

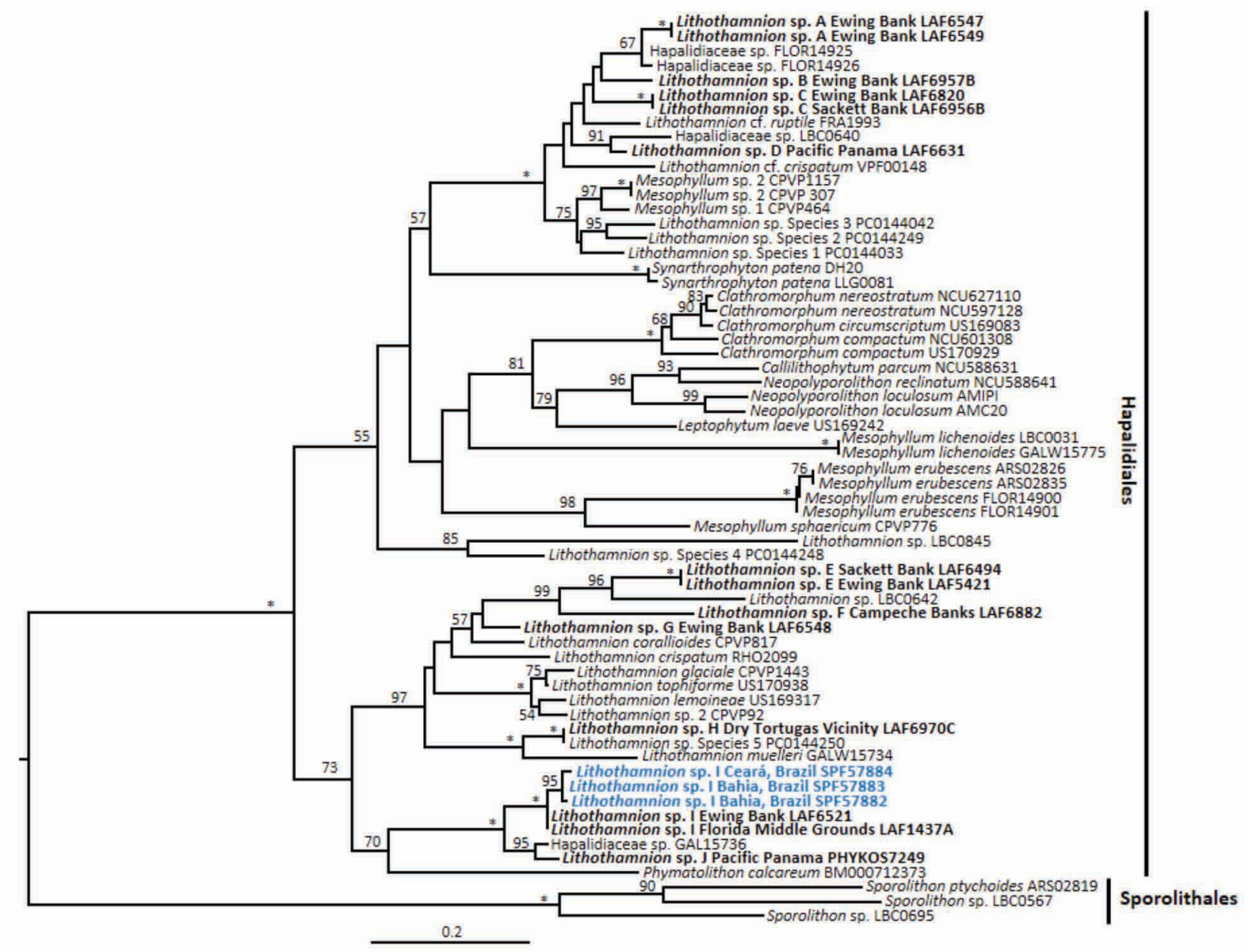

FIGURE 3. Phylogeny based on ML analysis of concatenated $p s b$, UPA, and COI sequences. Node values indicate bootstrap values out of 1,000 replicates. 


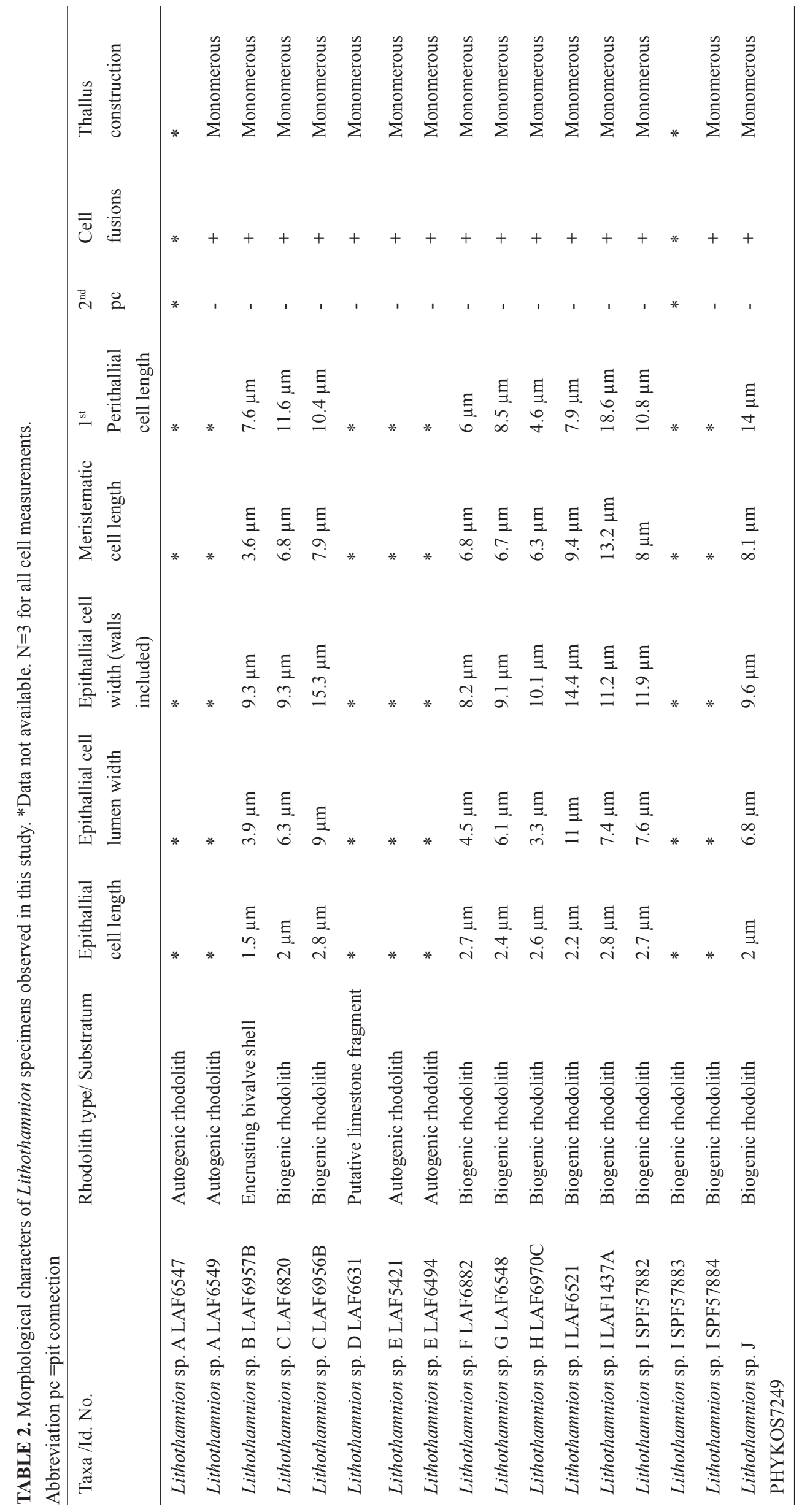




\section{Results}

\section{DNA sequence Analyses}

Species delimitation: Results of the ABGD and GMYC analyses (Figs. S1, S2) showed some discrepancies in the number of delimited molecular species for the entire data set. For example, Brazilian and GMx specimens of Lithothamnion sp. I were delimited as separate species in the GMYC analyses of $p s b \mathrm{~A}$ and COI, whereas those specimens were delimited as a single species in the ABGD analyses for those genes. To be conservative, we based the delimitation of the newly investigated specimens on the results of the ABGD analyses. Likewise, in the psbA tree, Hapalidiacae sp. LBC0640 and Lithothamnion sp. D were split in the GMYC analyses but delimited as a single species in the ABGD analyses. Aside from these differences, both analyses for both genes delimited all of the newly investigated specimens as at least 10 species, listed as Lithothamnion sp. A to J (Figs. S1, S2), eight of which are present in the GMx. Both analyses also delimited Lithothamnion sp. J and Hapalidiacae sp. GAL15736 as separate species and Lithothamnion sp. H and Lithothamnion Species 5-PC0144250 as a single species.

Phylogenetic Analyses: The backbones of the three single-gene phylogenies were overall poorly resolved (Figs. 1, 2, Fig. S3) whereas the multi-gene phylogeny (Fig. 3) was more resolved at deeper nodes. Numerous lineages harboring specimens fitting the morphological concept of Lithothamnion spp. (see next sections) received high support and overall, UPA, $p s b A$, and COI trees revealed previously undocumented molecular diversity for this genus found in the GMx, WTA, and Pacific Panama. In the psbA (Fig. 1) and multi-gene (Fig. 3) trees, Lithothamnion spp. are found in early branching paraphyletic lineages and in a strongly supported ( $p s b \mathrm{~A}, \mathrm{PP}=1, \mathrm{BS}=99$; multi-gene phylogeny, $\mathrm{BS}$ $=100$ ), monophyletic lineage sister to several lineages including members of the Clathromorphum Foslie complex of genera (sensu Adey et al. 2015), Mesophyllum Me.Lemoine, "Leptophytum" foecundum (Kjellman) W.H.Adey, and Synarthrophyton R.A.Townsend. All trees demonstrate that specimens identified as Lithothamnion sp. A-D comprise a lineage separate from other Lithothamnion spp. Several unresolved sequences labeled as Hapalidiaceae sp. branch within Lithothamnion clades, in psbA and COI trees (GAL15736, LBC0640), and in the UPA tree (FLOR14925, FLOR14926).

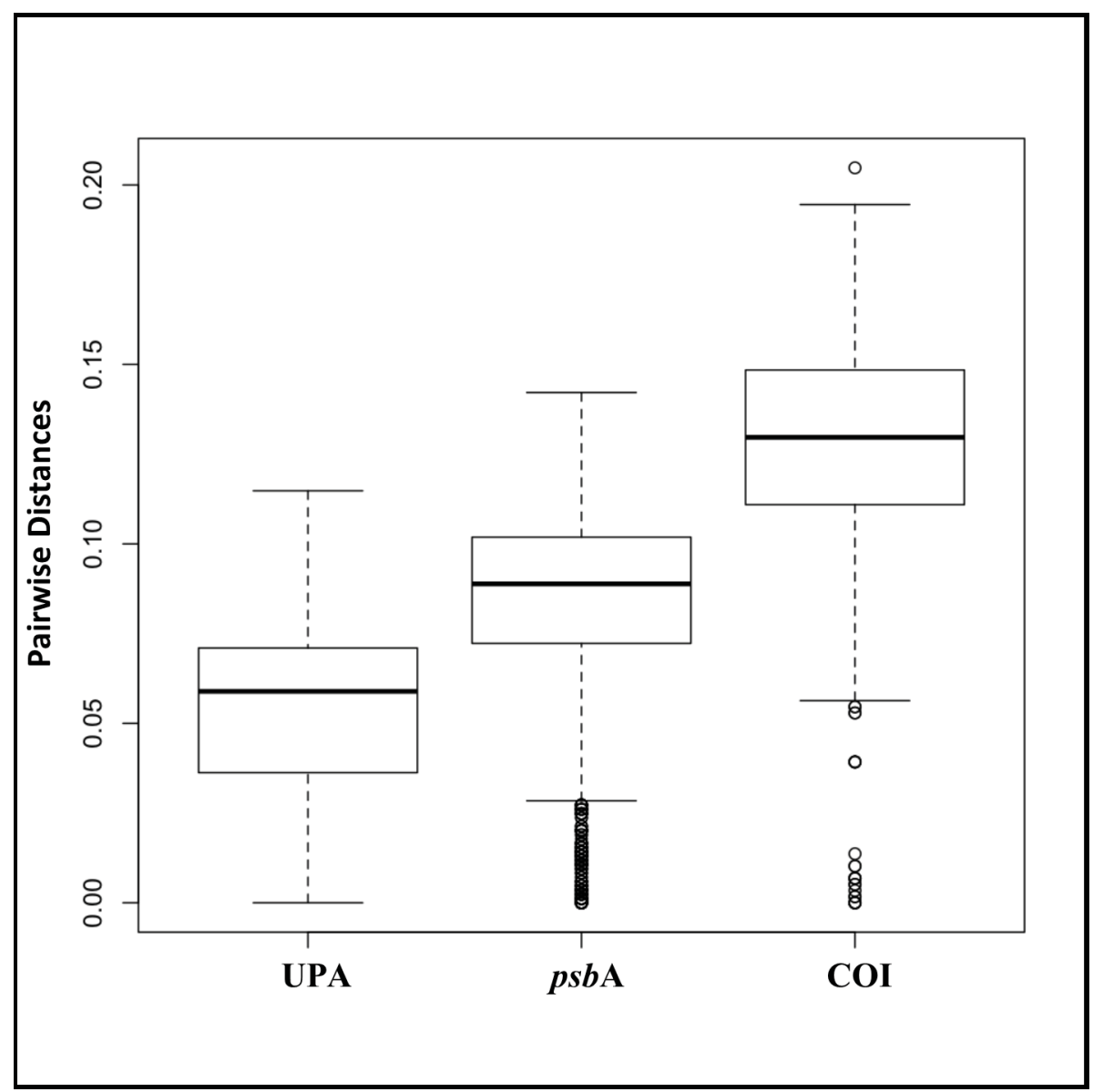

FIGURE 4. Distribution of raw pairwise distances (no. of base pair differences/alignment length) for each of the three markers analyzed in this study. 
Evaluation of pairwise distance distribution for the three markers as a proxy for these markers' speed of evolution and phylogenetic informativeness indicated that UPA is the most conserved, COI is the most variable, and $p s b \mathrm{~A}$ is in between (Fig. 4). Pairwise distances for each gene are reported in Tables S1-S3.

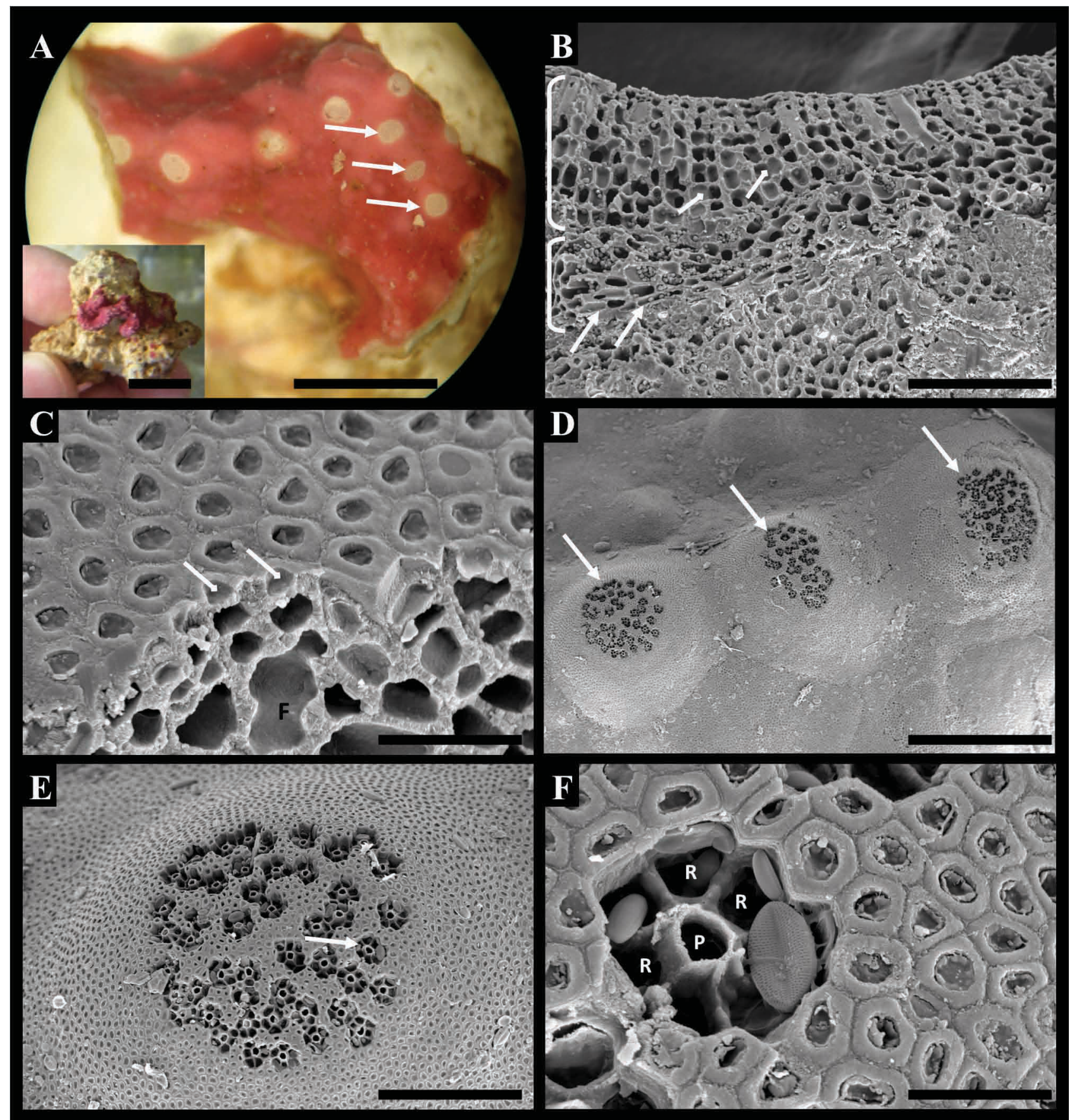

FIGURE 5. Lithothamnion sp. A. Specimen LAF6549. A. Dissecting microscope view showing habit of conceptacles (arrows) on thallus surface. Scale bar $1 \mathrm{~mm}$. Inset: Thallus habit growing on autogenic rhodolith. Scale bar $10 \mathrm{~mm}$. B. Vertical fracture through thallus showing hypothallium (lower bracket) with rectangular shaped cells (arrows) and perithallium (upper bracket) with cell fusions (small arrows). Scale bar $95 \mu \mathrm{m}$. C. Surface view and section of thallus showing epithallial cells (arrows) and cell fusion (F). Scale bar $25 \mu \mathrm{m}$. D. Surface view of thallus showing raised multiporate conceptacles (arrows). Scale bar $375 \mu \mathrm{m}$. E. Surface view of conceptacle showing pores, each surrounded by rosette cells (arrow). Scale bar $140 \mu \mathrm{m}$. F. Magnified view of pore (P) with rosette cells (R) indicated by arrow in Fig. 5E. Also shown are pennate diatoms. Scale bar $20 \mu \mathrm{m}$.

Morphological analysis: Scanning electron microscopy identified 17 specimens with characters corresponding to the genus Lithothamnion (see Table 2 for list of vegetative characters). In some specimens, intercalary meristematic cells were the same size or longer than the first perithallial cell derivatives. However, in other specimens meristematic cells were shorter than or approximately equal to the first perithallial cells. All crustose specimens had a dorsiventral 
orientation with a multilayered hypothallium consisting of hypothallial filaments with rectangular-shaped cells that were approximately isodiametric in cross section. All specimens possessed an epithallium that was typically single-layered, consisting of armored epithallial cells. Protuberant rhodolith specimens showed radial construction in vegetative protuberances (sometimes interspersed by new vegetative growth layers), whereas reproductive protuberances possessed radial construction interspersed by conceptacles and new vegetative growth layers. Crustose portions of protuberant rhodoliths were not sectioned to preserve the intact rhodolith as a morphological voucher specimen. Considering the molecular and morphological data, existing names could not be assigned with confidence to any of the species described below.

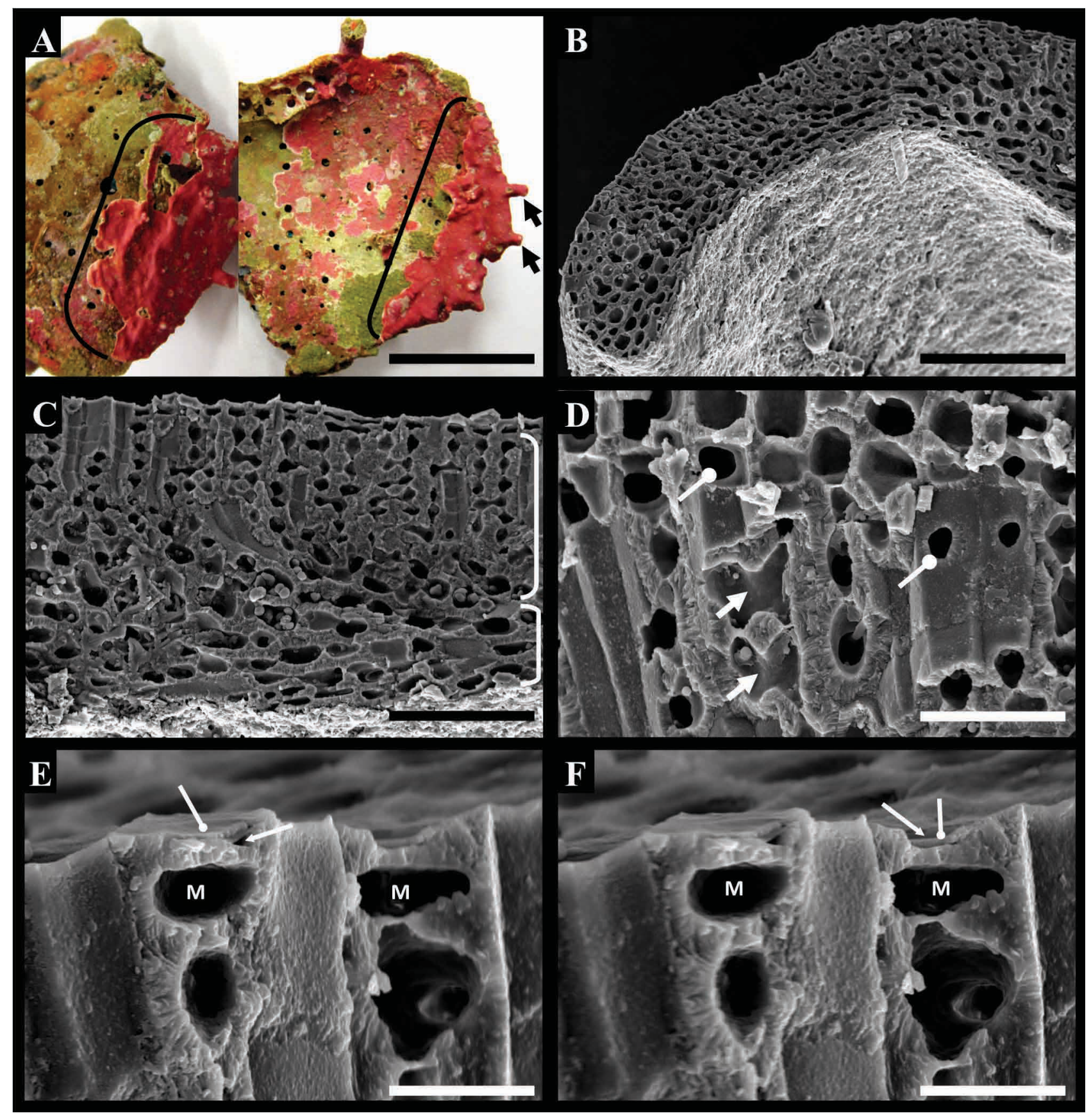

FIGURE 6. Lithothamnion sp. B. Specimen LAF6957B. A. Thallus habit (brackets) with some unbranched protuberances (arrows) growing on the top (left) and bottom (right) of an eroded bivalve shell. Scale bar $18 \mathrm{~mm}$. B. Vertical fracture of thallus showing thallus margin. Scale bar $100 \mu \mathrm{m}$. C. Vertical fracture of thallus showing hypothallium (lower bracket) and perithallium (upper bracket). Scale bar $55 \mu \mathrm{m}$. D. Perithallium showing cell fusions in the x-axis (arrows) and z-axis (circle arrows). Scale bar $24 \mu \mathrm{m}$. E.-F. Vertical fracture showing meristematic cells ("M"), left epithallial cell in focus (E.) with lumen (arrow) and intact epithallial cell roof (circle arrow) and right epithallial cell in focus (F.) with trapezoidal shaped lumen (arrow) and collapsed cell roof (circle arrow). Scale bar $8 \mu \mathrm{m}$. 


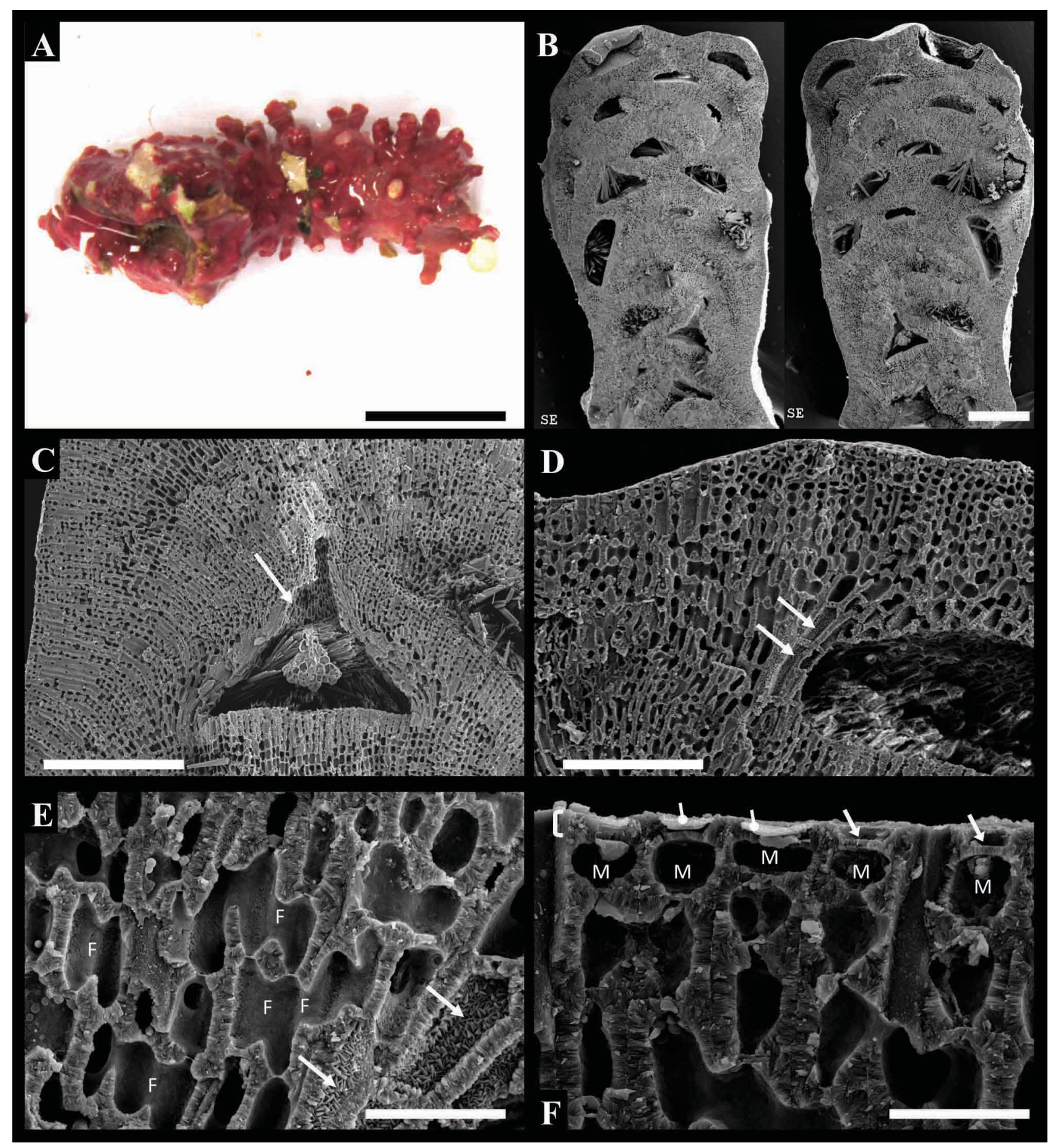

FIGURE 7. Lithothamnion sp. C. Specimen LAF6820. A. Thallus habit showing unbranched protuberances. Scale bar $12.5 \mathrm{~mm}$. B. Longitudinal sections of protuberance showing numerous overgrown conceptacles, many with putative aragonite infill. Sections are two halves of the same protuberance and show mirroring images of the same structures. Scale bar .5 mm. C. Overgrown uniporate conceptacle, arrow indicates conceptacle pore. Scale bar $240 \mu \mathrm{m}$. D. Conceptacle with elongated perithallial cells (arrows) located at the periphery. Scale bar $105 \mu \mathrm{m}$. E. Magnified view of area indicated by arrows in D. showing multiple fusions ("F") and centripetal infill of small, calcium carbonate crystals in cells bordering the conceptacles (arrows). Scale bar $17.5 \mu \mathrm{m}$. F. Epithallium (upper bracket), perithallium, and meristematic cells ("M"). Arrows indicate epithallial cell lumens and circle arrows indicate epithallial cell roofs. Scale bar $17.5 \mu \mathrm{m}$.

Lithothamnion sp. A Thallus construction and vegetative features: Specimens LAF6547 and LAF6549 (Fig. 5A-F) are separate crustose thalli with no protuberances epiphytic on the same autogenic rhodolith (Fig. 5A). Hypothallium with 2-4 layers of filaments that grow parallel to the substratum and give rise to upwardly branched perithallial filaments growing perpendicular to the substratum (Fig. 5B). Epithallial cells (Fig. 5C) with thick, heavily calcified cell walls. Meristematic cells were not clearly identified. 
Reproductive features: Surface views show multiporate conceptacles (Fig. 5D, E) with pores surrounded by 5-7 rosette cells (Fig. 5F). Spores were not visible in conceptacle sections (data not shown), and the conceptacles appeared post-spore release.

Lithothamnion sp. B Thallus construction and vegetative features: Specimen LAF6957B (Fig. 6A-F) is a loosely adherent crustose thallus with some protuberances (Fig. 6A) on an eroded bivalve shell with a lobed margin that appeared curved in section view (Fig. 6B). Hypothallium with 3-4 layers of filaments that give rise to branched tiers of perithallial filaments growing perpendicular to the substratum (6C). Perithallium with cell fusions shown in the $\mathrm{x}$ and Z-axis (Fig. 6D). Meristematic cells were smaller than their perithallial derivatives (Fig. 6E, F). Epithallial cells with a polygonal outline, trapezoidal shaped lumens and cell roofs that may remain intact (Fig. 6E) or become collapsed (Fig. 6F).

Reproductive features: Sections show raised conceptacles with respect to the surrounding thallus surface, some becoming filled in with crystals from secondary mineralization (Data not shown). It was not evident if conceptacles were uniporate or multiporate.

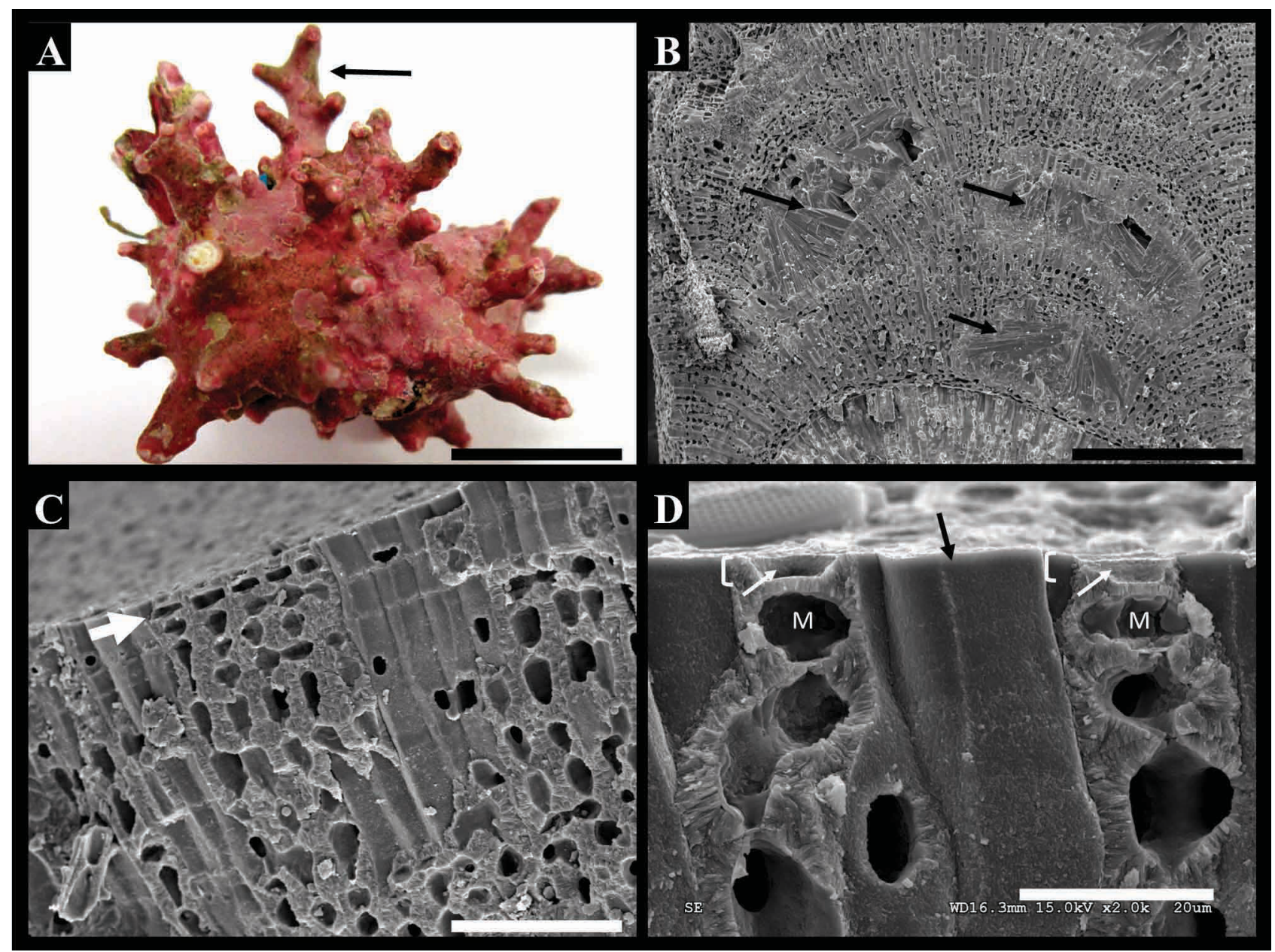

FIGURE 8. Lithothamnion sp. C. Specimen LAF6956B. A. Thallus habit showing occasionally branched (arrow) protuberances. Scale bar $11 \mathrm{~mm}$. B. Longitudinal section of protuberance showing overgrown conceptacles with spherical masses of putative aragonite (arrows). Scale bar $270 \mu \mathrm{m}$. C. Transverse section of protuberance showing meristematic cells (arrow) smaller than their perithallial derivatives. Scale bar $55 \mu \mathrm{m}$. D. Longitudinal section and partial surface view of thallus showing meristematic cells ("M") and epithallial cells lacking roofs (brackets) and trapezoidal lumens (arrows). Note heavily calcified filaments, one cleaved from the neighboring filament in the z-axis (black arrow) showing polygonal outline. Scale bar $20 \mu \mathrm{m}$.

Lithothamnion sp. C Thallus construction and vegetative features: Specimens LAF6820 (Fig. 7A-F) and LAF6956B (Fig. 8A-D) are both rhodoliths with numerous unbranched (Fig. 7A) or branched protuberances (Fig. 8A). Longitudinal sections show protuberances composed of abundant overgrown conceptacles, many with masses of putative aragonite crystals (Fig. 7B, Fig. 8B), interspersed between vegetative thallus layers. Conceptacles may have elongated perithallial cells at their periphery (Fig. 7D). Cells bordering some conceptacles show infill with small, centripetally formed calcite 
crystals (Fig. 7D, E). Perithallium with multiple cell fusions (Fig. 7E). Sections infrequently showed a secondary hypothallium over conceptacle roofs. Meristematic cells (Fig. 7F, Fig. 8C, D) as big or smaller than their perithallial derivatives. Epithallial cells with heavily calcified cell walls, a trapezoidal-shaped cell lumen and a thinner epithallial cell roof that may or may not remain intact (Fig. 7F, Fig. 8C, D).

Reproductive features: Longitudinal sections of LAF6820 show uniporate conceptacles (Fig. 7C), indicating they are either male or female, and sections of LAF6956B show conceptacles, though no pores were evident.

Additional Notes: Portions of the thallus of LAF6956B were very heavily calcified; the polygonal outline of filaments was shown where cells cleaved apart from their adjacent filaments in the z-axis (Fig. 8C, D).

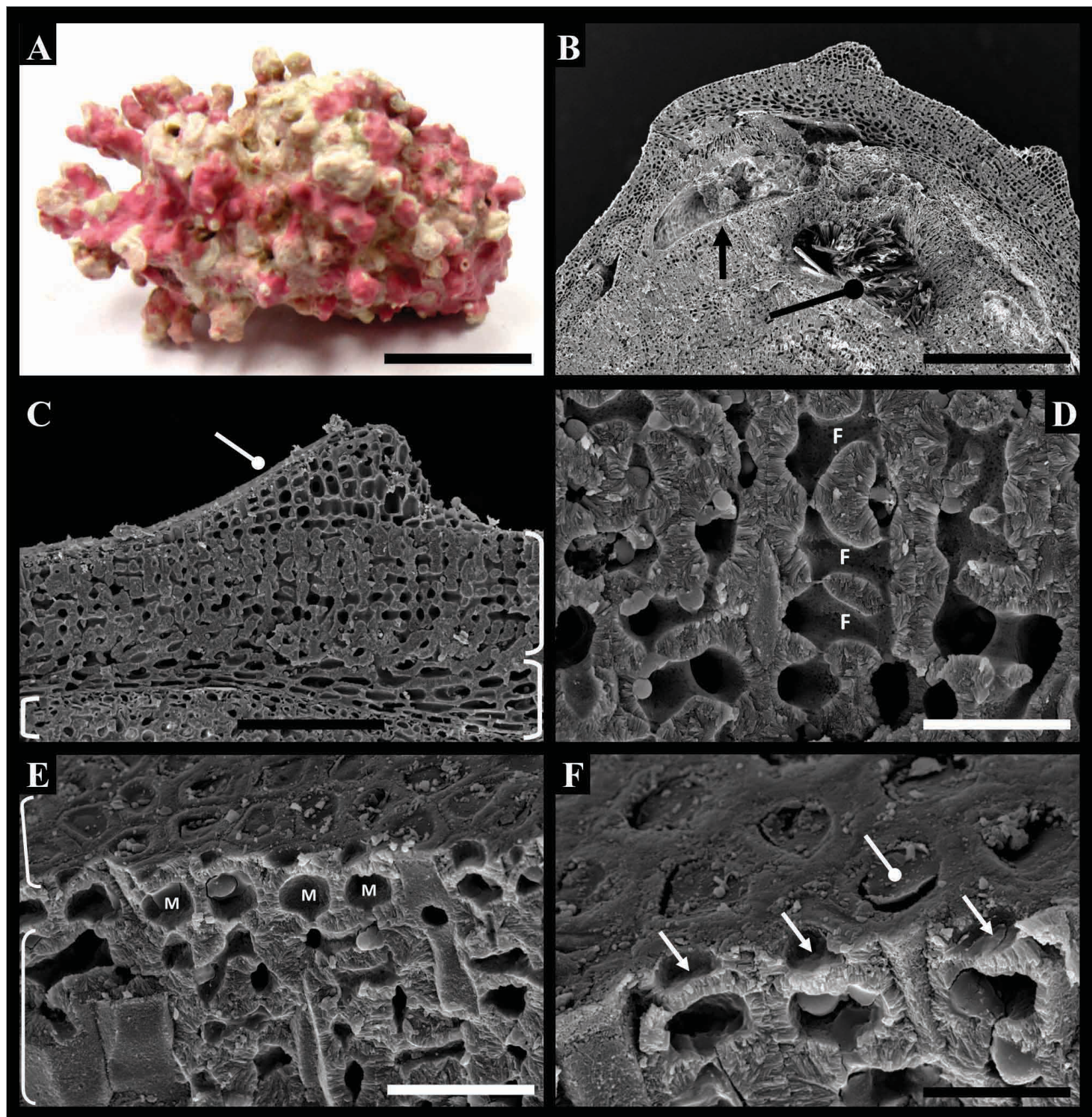

FIGURE 9. Lithothamnion sp. F. Specimen LAF6882. A. Thallus habit showing numerous protuberances. Scale bar $7 \mathrm{~mm}$. B. Section of protuberance showing two overgrown conceptacles (arrows), one including numerous putative aragonite crystals (circle arrow). Scale bar $290 \mu \mathrm{m}$. C. New growth layer growing over older part (left bracket) of the thallus showing secondary hypothallium (lower right bracket) and upwardly branched tiers of perithallial filaments (upper right bracket). Circle arrow indicates location of developing protuberance. Scale bar $90 \mu \mathrm{m}$. D. Perithallium with cell fusions (arrows). Scale bar $20 \mu \mathrm{m}$. E. Section and surface view showing perithallium (lower bracket), epithallium (upper bracket) and meristematic cells (M). Scale bar $28 \mu \mathrm{m}$. F. Magnified view of epithallial cells lacking cell roofs (arrows) and others with roof intact (circle arrow). Scale bar $10.5 \mu \mathrm{m}$. 
Lithothamnion sp. D Thallus construction and vegetative features: Specimen LAF6631 (Fig. S4A-F) possesses a thallus with no protuberances encrusting a small putative limestone nodule (Fig. S4A). Hypothallium with 5-10 layers of filaments that give rise to upwardly branched tiers of perithallial filaments (Fig. S4B). Perithallium with multiple cell fusions (Fig. S4C). Surface views of epithallium (Fig. S4D-F) show cells possess a polygonal outline. Partial section views show flattened epithallial cells each with a small lumen (Fig. S4D). Epithallial cell roofs (Fig. S4F) appear thin and collapsed into the cell lumen. Meristematic cells (Fig. S4E, F) as big or smaller than their perithallial derivatives.

Reproductive features: No reproductive features were observed.

Lithothamnion sp. E Thallus construction and vegetative features: Specimens LAF5421 (Fig. S5A, B) and LAF6494 (Fig. S5C, D) possess a thallus with no protuberances, encrusting autogenic rhodolith fragments (Fig. S5A). Hypothallium with 4-7 layers of filaments with rectangular shaped cells that give rise to upwardly branched tiers of perithallial filaments (Fig. S5B). Surface views show epithallium consists of cells with a polygonal outline and a roof that appears collapsed (Fig. S5C). Section and partial surface views show epithallial cells typically appear cleaved apart from neighboring cells rather than being sectioned (Fig. S5D), and clear views of the lumen were not obtained. Meristematic cells not clearly identified.

Reproductive features: No reproductive features were observed.

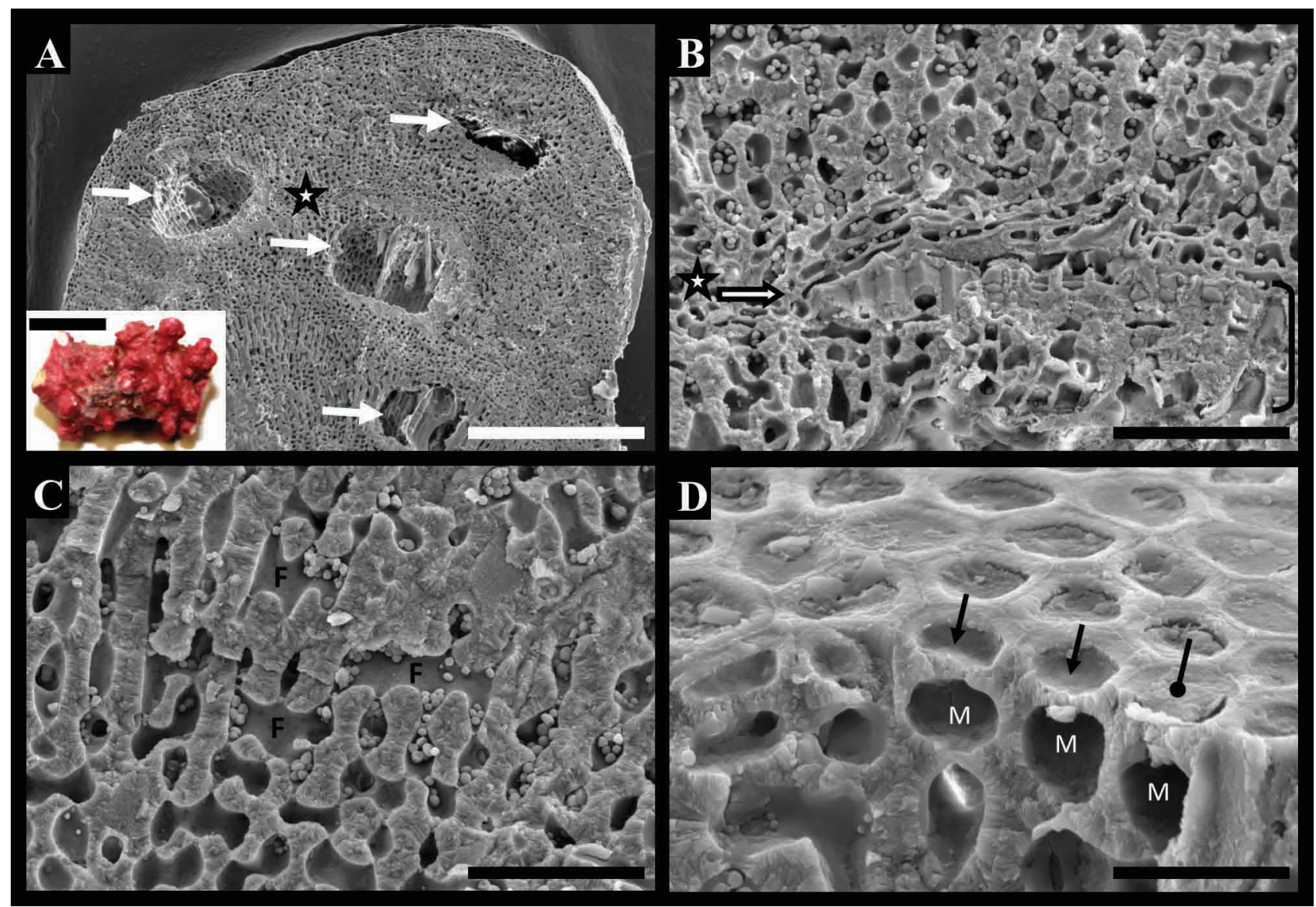

FIGURE 10. Lithothamnion sp. G. Specimen LAF6548. A. Longitudinal section through protuberance showing multiple overgrown conceptacles (arrows) and location of secondary hypothallium (star). Scale bar $250 \mu \mathrm{m}$. Inset: Thallus habit with unbranched protuberances. Scale bar $5 \mathrm{~mm}$. B. Magnified view of location indicated by the star in Fig. 10A showing secondary hypothallium (arrow) growing over the conceptacle roof. Scale bar $43 \mu \mathrm{m}$. C. Perithallium showing multiple fusions (F). Scale bar $30 \mu \mathrm{m}$. D. Section and surface view showing epithallial cells (arrows) with polygonal outline and trapezoidal shaped lumen. Circle arrow indicates epithallial cell with intact roof. Scale bar $13 \mu \mathrm{m}$.

Lithothamnion sp. F Thallus construction and vegetative features: Specimen LAF6882 (Fig. 9A-F) is a rhodolith that possesses numerous, occasionally branched protuberances (Fig. 9A). Longitudinal sections of protuberances show overgrown conceptacles (Fig. 9B) that in some locations become filled in with putative aragonite crystals from secondary mineralization. Conceptacles and older parts of the thallus become overgrown by the formation of a 
secondary hypothallium with 2-7 layers of filaments that give rise to upwardly branched tiers of perithallial filaments (Fig. 9C) that may develop new protuberances or add volume to existing protuberances. Perithallium with abundant cell fusions (Fig. 9D). Meristematic cells larger than their perithallial derivatives (Fig. 9E). Epithallial cells with thick, heavily calcified cell walls (Fig. 9E, F) that have a polygonal outline in surface view and an epithallial cell roof (Fig. 9F, circle arrow) that is missing from cells shown in cross section.

Reproductive features: It was not evident if conceptacles were uniporate or multiporate.

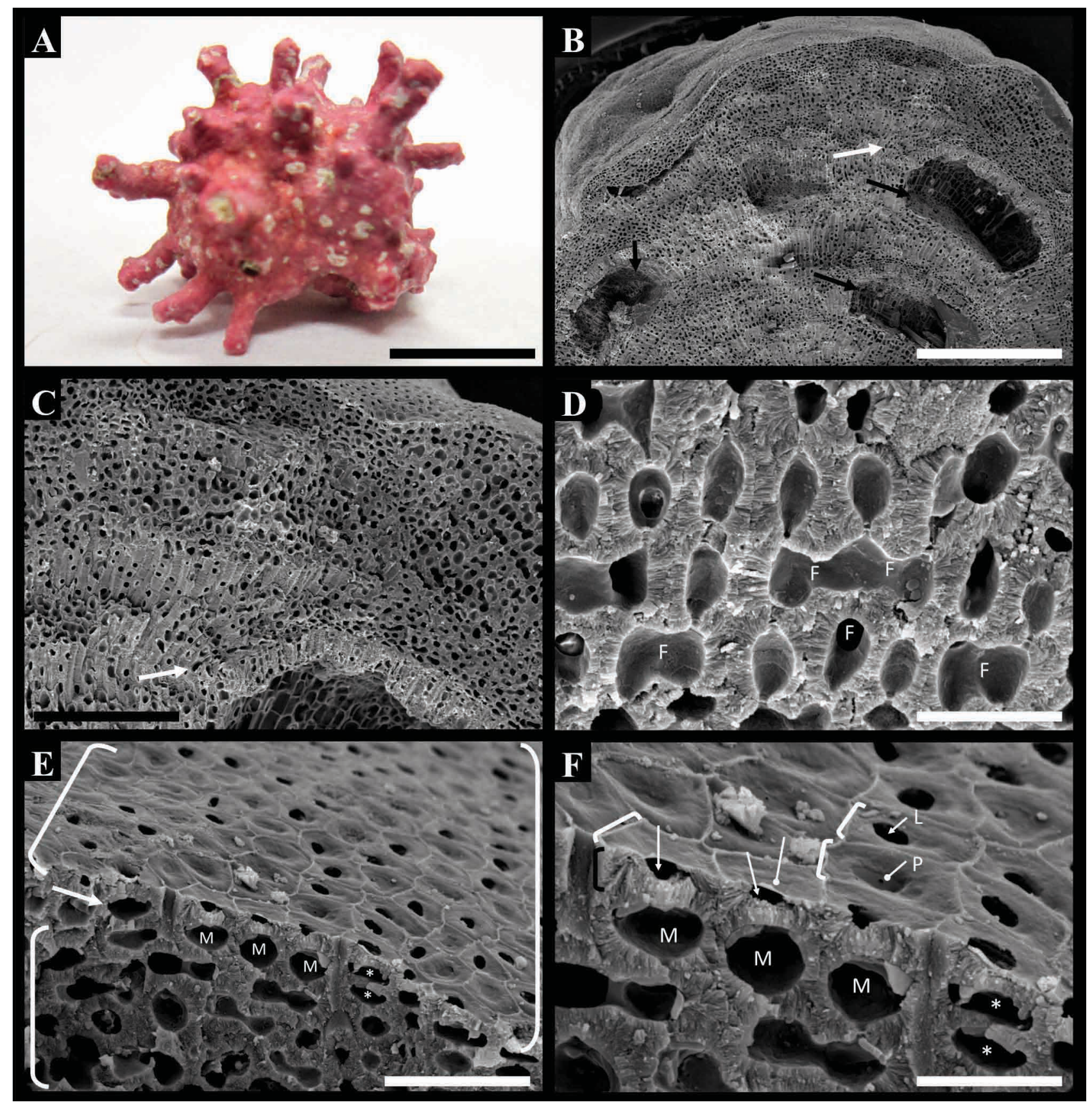

FIGURE 11. Lithothamnion sp. H. Specimen LAF6970C. A. Thallus habit showing unbranched protuberances. Scale bar $5 \mathrm{~mm}$. B. Longitudinal section and partial surface view of protuberance showing overgrown conceptacles (arrows). Scale bar $290 \mu \mathrm{m}$. C. Magnified view of area indicated by white arrow in B. showing secondary hypothallium growing over an empty conceptacle (white arrow). Scale bar $110 \mu \mathrm{m}$. D. Perithallium with multiple fusions ("F"). Scale bar $17 \mu \mathrm{m}$. E. Section and surface view of thallus showing epithallium (upper brackets), perithallium (lower left bracket) and meristem (arrow, "M", *). Scale bar $24 \mu \mathrm{m}$. F. Magnified view of same location shown in E. showing meristematic cells ("M"), putative recently divided meristematic cells (*) and section and surface views of epithallial cells (brackets) showing a polygonal outline in surface view, thick cell walls, small round lumens (arrows, "L"), epithallial cell roofs (circle arrows) with one showing primary pit connection ("P"). Scale bar $12 \mu \mathrm{m}$. 
Lithothamnion sp. G Thallus construction and vegetative features: Specimen LAF6548 (Fig.10A-D) is a rhodolith with numerous unbranched protuberances (Fig. 10A). Longitudinal sections of protuberances show conceptacles (Fig. 10A) become overgrown by a secondary hypothallium with 2-3 layers of filaments (Fig. 10B) that gives rise to new perithallial filaments. Perithallium with abundant multiple fusions (Fig. 10C). Meristematic cells (Fig. 10D) typically as big or smaller than perithallial derivatives. Epithallial cells (Fig. 10D) with thick, heavily calcified cell walls and slightly trapezoidal shaped lumens (arrows) with a polygonal cell outline in surface view.

Reproductive features: It was not evident if conceptacles were uniporate or multiporate.
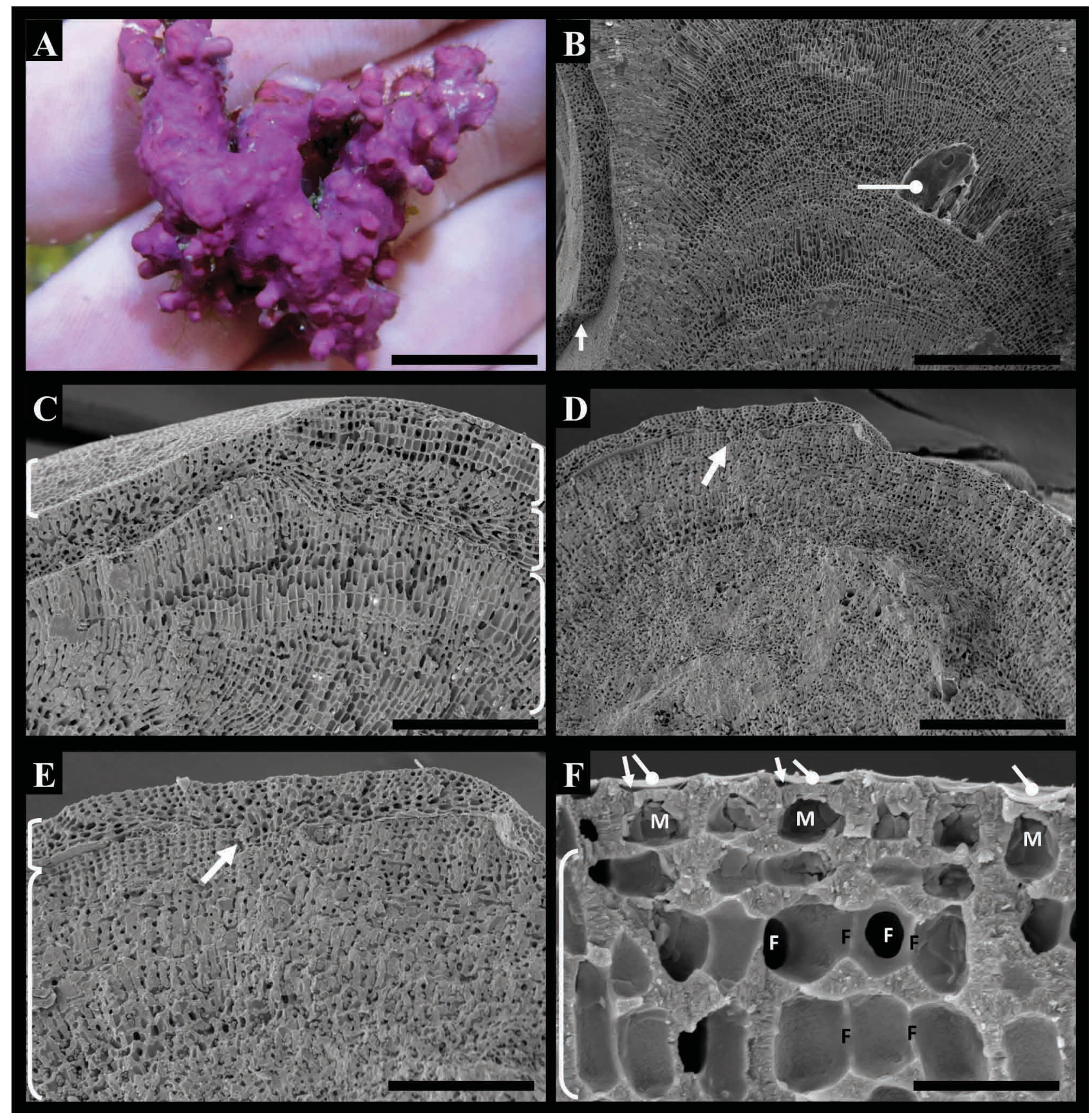

FIGURE 12. Lithothamnion sp. I. Specimen LAF6521. A. Thallus habit showing irregularly arranged protuberances. Scale bar 150 $\mathrm{mm}$. B. Longitudinal section and partial surface view of protuberance showing putative undeveloped conceptacle (circle arrow) and new vegetative growth layer (arrow). Scale bar $450 \mu \mathrm{m}$. C. Longitudinal section and partial surface view of protuberance showing magnified view of new growth layer with secondary hypothallium (middle right bracket), perithallium (upper right bracket), and epithallium (left bracket) growing above older growth layer (lower right bracket). Scale bar $240 \mu \mathrm{m}$. D. Transverse section of protuberance showing radial construction and location of new growth layer over older part of thallus (arrow). Scale bar $400 \mu \mathrm{m}$. E. Magnified view of new growth layer (upper bracket) emerging out of perithallium (arrow) of older growth layer (lower bracket). Scale bar $195 \mu$ m. F. Perithallium (bracket) with abundant cell fusions in the x-axis ("black F") and z-axis (white "F"), meristematic cells ("M"), and epithallial cells with trapezoidalshaped cell lumens (arrows) and intact roofs (circle arrows). Scale bar $24 \mu \mathrm{m}$. 


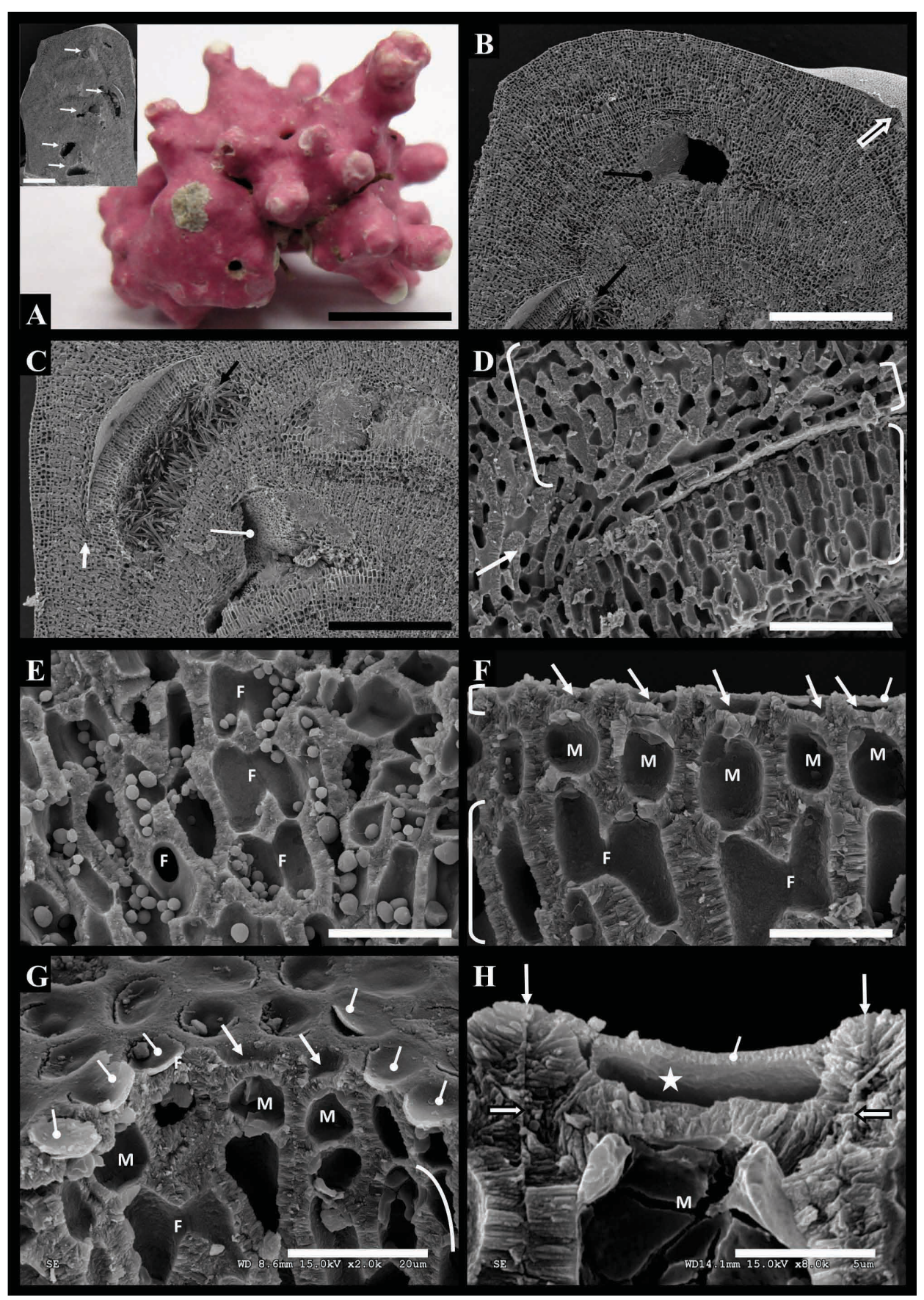

FIGURE 13. Lithothamnion sp. I. Specimen LAF1437A. A. Thallus habit showing unbranched protuberances. Scale bar $5 \mathrm{~mm}$. Inset: longitudinal section of protuberance with multiple overgrown conceptacles (white arrows). Scale bar .7 mm. B. Longitudinal section and partial surface view of same protuberance shown in Fig. 13A., inset, showing overgrown conceptacles with spherical mass of aragonite (circle arrow) and aragonite in the form of needles (arrow). White and black arrow indicates location shown in G. Scale bar $500 \mu \mathrm{m}$. C. Same protuberance shown in Fig. 13A (inset), and Fig. 13B, showing uniporate conceptacles with aragonite infill (black arrow) and longitudinal section of conceptacle pore (white circle arrow). Scale bar $400 \mu \mathrm{m}$. D. Magnified view of area indicated by white arrow in Fig. 13C showing secondary hypothallium (upper right bracket) and perithallium (left bracket) growing over the conceptacle roof (lower right bracket). Scale bar $70 \mu \mathrm{m}$. E. Perithallium with cell fusions ("F"). Scale bar $35 \mu \mathrm{m}$. F. Meristematic cells ("M") shorter than perithallial derivatives (bracket) with cell fusions ("F"), and epithallial cells with trapezoidal shaped lumens, one showing an intact epithallial cell roof (circle arrow). Scale bar $17.5 \mu \mathrm{m}$. G. Curved fracture region of longitudinal section and surface view of portion of thallus indicated in 13B. showing perithallium ( $\operatorname{arc}$ ) with cell fusion ("F"), meristematic cells ("M") and epithallial cells lacking intact roofs showing trapezoidal shaped cell lumens and other epithallial cells showing intact roofs (circle arrows). Scale bar $20 \mu \mathrm{m}$. H. Magnified view of epithallial cell (upper cell, star indicates cell lumen) with intact roof (circle arrow) and partial view of meristematic cell ("M") showing ultrastructure of calcified cell walls. Arrows indicate the four corners of the epithallial cell; white arrows indicate boundaries of adjacent filament cell walls, black arrows with white fill indicate boundary between epithallial cell wall and meristematic cell wall. Scale bar $5 \mu \mathrm{m}$. 


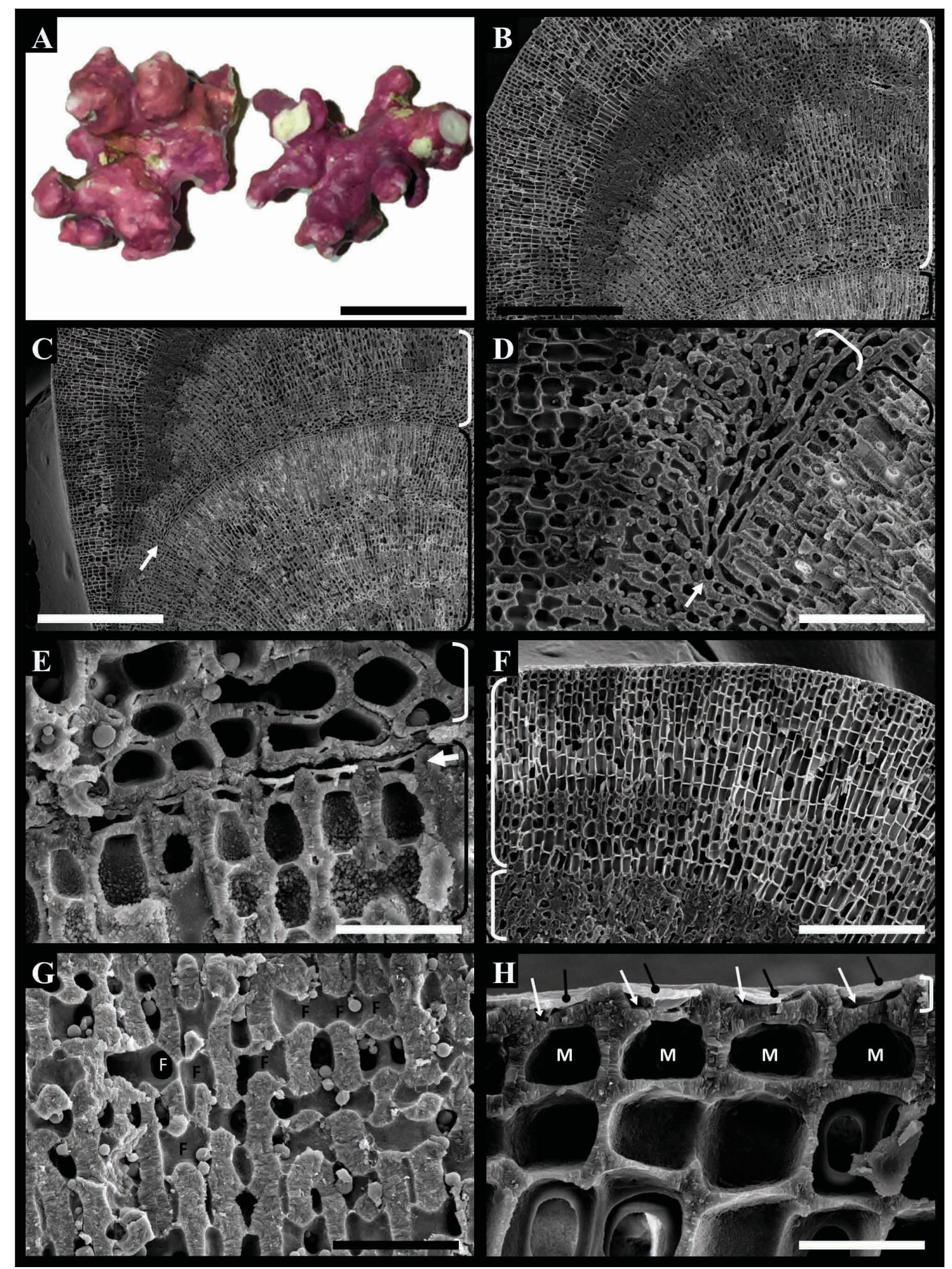

FIGURE 14. Lithothamnion sp. I. Specimen SPF57882. A. Habit of specimen showing typically unbranched protuberances (two fragments represent a single specimen which was fractured during preparation for DNA extraction and SEM). Scale bar $1 \mathrm{~cm}$. B. Longitudinal section of protuberance showing location of new (white bracket) and older (black bracket) growth layers. Scale bar $300 \mu \mathrm{m}$. C. Same protuberance shown in Fig. 14B showing location of secondary hypothallium (white arrow) over surface of older growth layer (black bracket). Scale bar $350 \mu \mathrm{m}$. D. Magnified view of secondary hypothallium (arrow, white bracket) showing rectangular shaped cells. Scale bar $70 \mu \mathrm{m}$. E. Cross section of secondary hypothallium showing round and polygonal outlines (white bracket) growing over intact cells of the epithallium (arrow) of older growth layer (black bracket). Scale bar $17.5 \mu \mathrm{m}$. F. Longitudinal section of thallus showing layer of perithallium with thick, heavily calcified cell walls (lower bracket) and a layer with thin, weakly calcified cell walls (upper bracket). Scale bar $140 \mu \mathrm{m}$. G. Perithallium with cell fusions ("F"). Scale bar $35 \mu \mathrm{m}$. H. Epithallial cells with trapezoidal shaped cell lumens (arrows) and intact epithallial cell roofs (circle arrows) and meristematic cells ("M"). Scale bar $14 \mu \mathrm{m}$. 

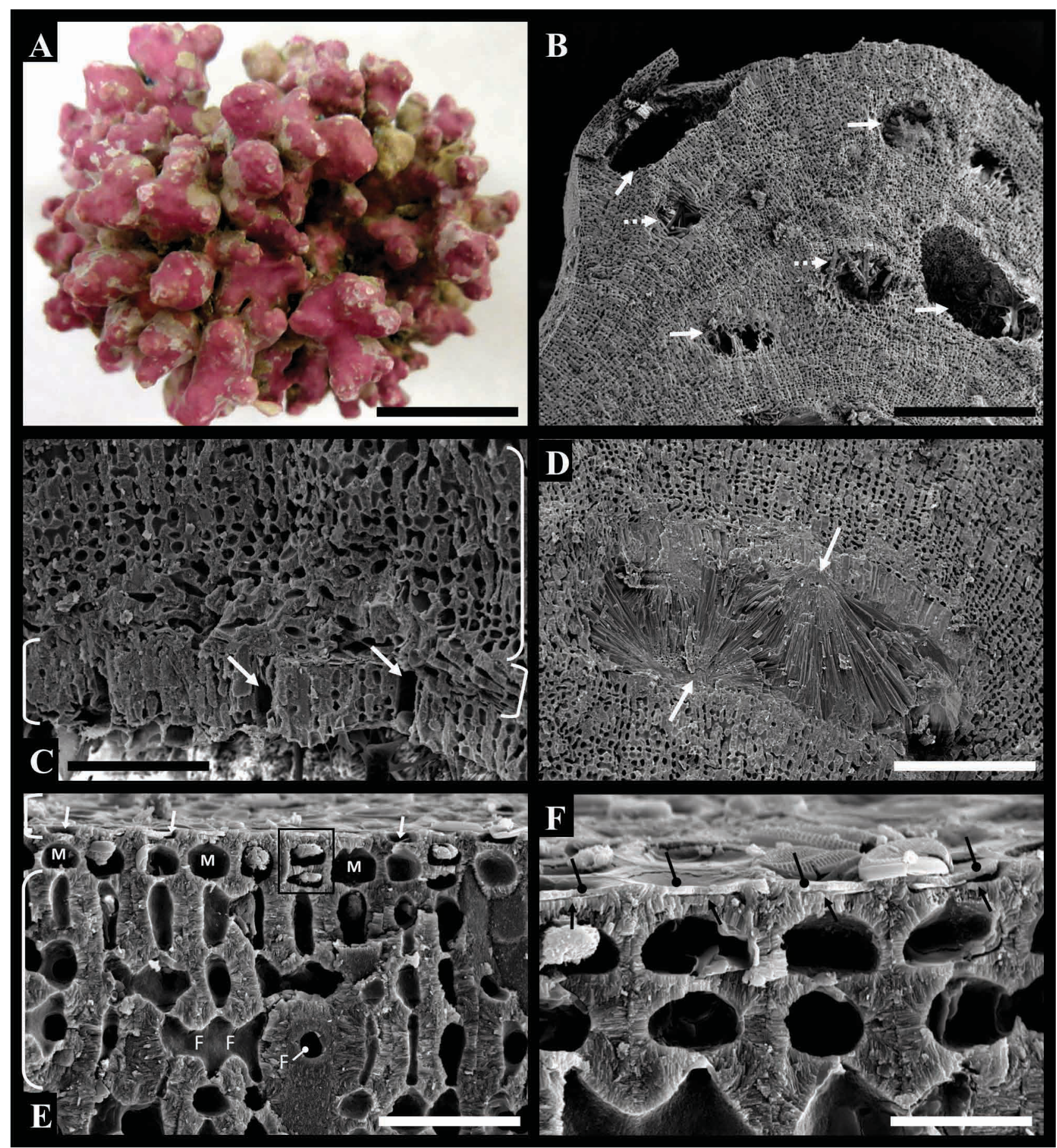

FIGURE 15. Lithothamnion sp. J. Specimen PHYKOS7249. A. Thallus habit showing unbranched protuberances. Scale bar 20 mm. B. Longitudinal section of protuberance showing overgrown conceptacles (arrows), some filled with aragonite crystals (perforated arrows). Scale bar $400 \mu \mathrm{m}$. C. Longitudinal section of protuberance showing secondary hypothallium (lower right bracket) and perithallium (upper right bracket) growing over conceptacle roof (left bracket) with pores (arrows). Scale bar $70 \mu \mathrm{m}$. D. Overgrown conceptacle with aragonite infill in the form of spherical masses, forming from the conceptacle roof and floor (arrows). Scale bar $180 \mu \mathrm{m}$. E. Perithallium (lower bracket) with cell fusions ("F", circle arrow), meristematic cells ("M") and recently divided meristematic cells (black outline), and section and partial surface view of epithallium (upper bracket). Epithallial cells lacking intact roofs (arrows) showing trapezoidal shaped lumens. Scale bar $30 \mu \mathrm{m}$. F. Epithallial cells with intact roof (circle arrows) and proximal cell wall (arrows). Scale bar $12 \mu \mathrm{m}$.

Lithothamnion sp. H Thallus construction and vegetative features: Specimen LAF6970C (Fig. 11A-F) is a small rhodolith with unbranched protuberances (Fig. 11A). Longitudinal sections sections show protuberances composed of vegetative filaments interspersed by numerous overgrown conceptacles (Fig. 11B, C). Overgrowth is achieved by a secondary hypothallium over the conceptacle roof (Fig. 11B, C). Perithallium with multiple fusions (Fig. 11D). 
Longitudinal sections show meristematic cells larger than their perithallial derivatives and putative pairs of recently divided meristematic cells (Fig. 11E, F). Epithallial cells possess heavily calcified lateral and proximal cell walls, a very small cell lumen, and a thin, weakly calcified epithallial cell roof (Fig. 11E, F). Section views reveal the lumen in part and surface views of cells lacking the epithallial cell roof show the round lumen surface (Fig. 11E, F). Surface views of cells with intact epithallial cell roofs show primary pit connections in the center of the roof (Fig. 11F) appearing as a very small circular dark spot.

Reproductive features: It was not evident if conceptacles were uniporate or multiporate.

Lithothamnion sp. I Thallus construction and vegetative features: All specimens (LAF6521, LAF1437A, SPF57882, SPF57884) examined of this species are rhodoliths with typically unbranched protuberances (Figs. 12-14). Longitudinal and transverse sections of non-reproductive samples show protuberances composed largely of vegetative filaments (Figs. 12, 14). Longitudinal sections of the reproductive sample showed protuberances with numerous overgrown conceptacles (Fig. 13A) with aragonite infill in the form of needle-like crystals and spherical masses (Fig. 13B, C). A new growth layer was observed over the older thallus surface of vegetative specimens (Fig. 12B-E, 14B-E) and over each of the conceptacle roofs in the reproductive specimen (Fig. 13A-D). New growth layers developed from a secondary hypothallium comprised of 2-4 layers of filaments that grew over the older layer of thallus (Fig. 12C-E, Fig. 14C-E) or conceptacle roofs (Fig. 13D) and gave rise to upwardly branched tiers of perithallial filaments. Perithallium with multiple fusions (Fig. 12F, 13E, F, 14G), shown in the x-axis and z-axis of sections. Meristematic cells were either larger than (Fig. 12F), approximately equal in size to (Fig. 14H), or smaller than their perithallial derivatives (Figs. 13F, G). Epithallial cells (Figs. 12E, 13F-H, 14E, H) with heavily calcified proximal and lateral cell walls that are thickest at the proximal end of the lateral walls and become thinner near the distal end, a trapezoidal shaped cell lumen, and a thinner, weakly calcified epithallial cell roof that is sometimes missing in sections. Epithallial cells may remain intact (Fig. 12E) upon being buried by the secondary hypothallium.

Reproductive features: Overgrown conceptacles were identified in specimens LAF6521 (Fig. 12B, circle arrow) and SPF57882 but no diagnostic characters were evident to indicate if conceptacles were gametangial or tetrasporangial. Longitudinal sections of LAF1437A show conceptacles are uniporate (Fig. 13C, white circle arrow) indicating they are either male or female.

Additional notes: The perithallium of specimen SPF57882 consists of filaments with alternating layers of cells with thick, heavily calcified cell walls and cells with thin, weakly calcified cell walls (Fig. 14F).

Lithothamnion sp. J Thallus construction and vegetative features: Specimen PHYKOS7249 (Figs. 15A-F) is a rhodolith with unbranched protuberances (Fig. 15A). Longitudinal sections of protuberances show overgrown conceptacles (Fig. 15B), that frequently become filled in with aragonite crystals. Secondary hypothallium was observed over old conceptacle roofs (Fig. 15C) and gave rise to the next layer of perithallium. Perithallium with multiple fusions (Fig. 15E). Intercalary meristematic cells were identified, as well as putative recently divided meristematic cells (Fig. 15E). Epithallial cells (Fig. 15E, F) with a trapezoidal shaped lumen. In some locations sections show epithallial cells with very little space between the epithallial cell roof and the proximal epithallial cell wall (Fig. 15F).

Reproductive features: Longitudinal sections show multiporate conceptacles roofs (Fig. 15C).

Additional notes: Sections show aragonite crystals in-filled empty conceptacles and grew from the roof and floor. Aragonite showed two forms; spherical masses (Fig. 15D) and needle-like crystals with a hexagonal outline.

\section{Discussion}

Polyphyly of Lithothamnion. Phylogenetic trees of psbA (Fig. 1), COI (Fig. 2), and concatenated UPA, psbA, and COI sequences (Fig. 3) of species that morpho-anatomically would be placed in Lithothamnion indicate this genus is polyphyletic, as also demonstrated recently by Peña et al. (2014b) using psbA and COI. Our extensive SEM investigations show that species in both Lithothamnion clades (Figs. 1-3) have the currently recognized, diagnostic characters of the genus, but also lack obvious distinguishing morpho-anatomical characters that would support recognizing the two main clades identified here as distinct genera. Moreover, we do not know to which clade the generitype species of Lithothamnion, L. muelleri belongs. The $p s b$ A sequence of L. muelleri in GenBank derives from a specimen from Isla San José, Gulf of California, Mexico that in light of our results showing cryptic diversity in this group of coralline algae, could have been misidentified, especially considering that the type locality of $L$. muelleri is 
in the state of Victoria in southern Australia. DNA sequences generated from the lectotype specimen of L. muelleri, housed at CN (Woelkerling 1983), would help clarify the relationship between this southern hemisphere species and the northern hemisphere specimen identified as L. muelleri, and may also shed light on the relationships between other southern and northern hemisphere species of Lithothamnion.

Lithothamnion GMx species. Results from the psbA analysis (Fig. 1) indicated that the lineage harboring Lithothamnion spp. A, B, C, and D was well-supported and separate from other northern hemisphere Lithothamnion spp. Included in this former lineage were specimens collected from subtidal depths (5-50m) offshore Guadeloupe, F.W.I investigated in Peña et al. (2014b) and identified based on morpho-anatomy as Lithothamnion spp. (called Species 1, 2, and 3), L. cf. ruptile (type locality: Puerto Plata, Dominican Republic), as well as L. cf. crispatum collected from the Mediterranean Sea. Peña et al. (2014b) showed in their $p s b$ A analysis that these specimens comprised a strongly supported lineage separate from the lineage comprised of L. glaciale Kjellman, L. corallioides (P.Crouan \& H.Crouan) P.Crouan \& H.Crouan and Gulf of California L. muellerii, and noted that obtaining DNA sequences from the type specimens of L. ruptile, L. crispatum, and L. occidentale would aid in clarifying relationships between this lineage and other Lithothamnion spp.

Interestingly, sequences of specimens identified as Mesophyllum sp. 1 and 2, from subtidal depths in the vicinity of Macaronesia (20 and 15m, respectively) investigated by Pardo et al. (2014) also are nested within this lineage and comprise a clade with Lithothamnion spp. (Species 1, 2, and 3) from Guadeloupe. Pardo et al. (2014) reported that these specimens shared morphological characters with Lithothamnion spp. but concluded that the specimens belonged in Mesophyllum based on the results of the molecular analyses, which indicated that these specimens were sister to Mesophylum sphaericum V.Peña, Bárbara, W.H.Adey, Riosmena-Rodríguez \& H.G.Choi with strong support. With a larger sample size, we show here that M. sphaericum is sister to M. erubescens (Foslie) Me.Lemoine with strong support in the $p s b \mathrm{~A}$ tree ( $\mathrm{PP}=0.99, \mathrm{BS}=92 \%)$ (Fig. 1) and in the multi-gene tree (BS=98\%) (Fig. 3), and not closely related to Mesophyllum sp. 1 and 2. Unidentified Hapalidiaceae specimens from New Caledonia and Brazil are also nested within this clade, indicating that this lineage has a wide distribution.

Lithothamnion spp. E and F show a close relationship with Lithothamnion sp. LBC0642 in the psbA, COI, and multi-gene trees (Figs. 1-3) and comprise a lineage that is well supported in both Bayesian (psbA PP=.98, COI PP= .94 ) and $\mathrm{ML}$ analyses ( $p s b \mathrm{~A}, \mathrm{BS}=80 \%, \mathrm{COI}, \mathrm{BS}=94 \%$, multi-gene analysis, $\mathrm{BS}=99 \%$ ). In the $p s b \mathrm{~A}$ tree, this lineage comprises a clade at the base of the Hapalidiales whereas in the COI tree, this clade is sister to L. corallioides. Taking into account the results of the pairwise distance distribution analysis (Fig. 4), this may be a result of psbA being more conserved than COI, considering that studies in other taxonomic groups have shown conserved genes lead to paraphyletic relationships and unresolved phylogenies (Maia et al. 2012).

The COI sequence of Lithothamnion sp. H (LAF6970C), collected from 69m depth in the SEGMx, is $100 \%$ identical to the COI sequence of a specimen identified as Lithothamnion Species 5 PC0144250 collected from 110m depth offshore Guadeloupe, F.W.I. investigated in Peña et al. (2014b). In the COI and multi-gene trees (Figs. 2, 3) these two specimens are sister to other Lithothamnion spp., including L. glaciale and L. corallioides.

The close relationship between specimens of Lithothamnion spp. I and J and specimen GAL15736 is intriguing considering Hernández-Kantún et al. (2015) showed that GAL15736 possessed "flared" epithallial cells. This lineage received strong support in the single-gene analyses of $p \sin (\mathrm{PP}=1, \mathrm{BS}=100 \%)$ and $\mathrm{COI}(\mathrm{PP}=1, \mathrm{BS}=90 \%)$ and in the multi-gene phylogeny $(\mathrm{BS}=100 \%)$. Although UPA sequences of specimens of Lithothamnion sp. I from the GMx and Brazil were identical (Fig. S3, Table S1), some distance was observed in both the $p s b$ A and COI datasets (Figs. 1, 2, Tables S2, S3). ABGD analyses for both $p s b \mathrm{~A}$ and $\mathrm{COI}$ indicate the specimens from the GMx and Brazil are conspecific whereas GMYC analyses indicate two species should be recognized. These results indicate that the specimens comprising Lithothamnion sp. I may represent a single species, separate species or separate taxa below the rank of species, though additional samples from other localities are needed to examine the range of DNA sequence variation in this clade and neighboring clades (see Hind et al. 2015 for more information regarding DNA sequence variation and species boundaries). Results of the $p s b$ A analysis (Fig. 1) are similar to the results of the $p s b$ A analysis presented by Hernández-Kantún et al. (2015, fig. 2) with regards to the relationship between Lithothamnion spp., Phymatolithon calcareum (Pallas) W.H.Adey \& McKibbin, and Hapalidiaceae sp. GAL15736.

Results of the phylogenetic and species delimitation analyses indicate that the newly generated sequences represent at least ten species, with eight from the GMx. These results show that there are more species corresponding to Lithothamnion sensu lato than there are available names for this genus in the GMx, namely L. occidentale (Foslie) Foslie, L. sejunctum, and L. crispatum. For example, five species, C, F, G, H and I all appear to conform somewhat to the morpho-anatomical species concept of L. occidentale (type locality: Cruz Bay, St. John Island, US Virgin Islands), a species reported for the GMx (Dawes 1974, Fredericq et al. 2009, Mateo Cid et al. 2014). DNA sequencing needs to 
be performed on the type specimen of L. occidentale and the morpho-anatomy of the specimen needs to be examined carefully before this species epithet can be assigned with confidence to any of the specimens examined.

Rhodolith specimens reported by Mateo-Cid et al. (2014b, p. 228, fig. 2) as L. crispatum, may correspond to Lithothamnion sp. F (LAF6882), considering this specimen was collected at the same time and collecting cruise location (from 50m in the SWGMx near the Campeche Banks, Mexico) as the samples presented in Mateo-Cid et al. (2014b). The psbA sequence of a specimen collected in the Mediterranean Sea, Spain, identified as L. cf. crispatum (Peña et al. 2014b) and the psbA sequences of the taxon identified as L. crispatum (Nelson et al. 2015) appear distantly related and are not conspecific with any of the newly sequenced taxa. DNA sequencing of the lectotype specimen of L. crispatum (Basso et al. 2011), needs to be performed before this name can be applied with confidence to specimens from the GMx.

Minnery (1990) reported three species of Lithothamnion for the Flower Garden Banks, including two unnamed species and one reported as 'L. sejunctum?'. Lithothamnion sejunctum (type locality: U.S. Virgin Islands), reported by Taylor (1960) to be epilithic and encrusting, may correspond to Lithothamnion spp. A, B, or E. Lithothamnion sp. B, specimen LAF6957B from Sackett Bank, possesses lobed, white margins, a character reported for L. sejunctum (Taylor, 1960), but it also has a loosely adherent crust, which is in contrast to Taylor's description of L. sejunctum as "strongly adherent" (Taylor 1960, p. 381). Lithothamnion spp. A, E possess strongly adherent crusts but do not possess lobed margins. DNA sequencing of the type specimen of L. sejunctum will help clarify if this species corresponds to specimens in the current study.

Lithothamnion ruptile is described as having an encrusting morphology (Taylor 1960). This species may correspond to the encrusting specimens Lithothamnion spp. A, B, or E. Interestingly, the specimen identified as $L$. cf. ruptile is closely related to Lithothamnion sp. A, and included in this lineage is Lithothamnion sp. B. However, both $\mathrm{ABGD}$ and GMYC analyses indicate that the psbA sequence of $L$. cf. ruptile is not conspecific with Lithothamnion sp. A or B, nor is it conspecific with any other taxon in the $p s b \mathrm{~A}$ tree. DNA sequencing of the holotype specimen of $L$. ruptile (basionym: Lithothamnion syntrophicum $\mathrm{f}$. ruptile), will help clarify if any of the specimens in the current study correspond to that species.

More recently, Lithothamnion carpoklonium Athanasiadis \& D.L.Ballantine was described from shallow water in the Caribbean Sea. This species, which possesses a crustose morphology and also bears protuberances, is similar in habit to Lithothamnion sp. B. However, L. carpoklonium was discovered growing on mangrove prop roots, whereas Lithothamnion sp. B was found encrusting a bivalve shell from $65-68 \mathrm{~m}$ depth. Peña et al. (2014b) noted that DNA sequencing of the holotype specimen of $L$. carpoklonium may help clarify the application of species names in the Caribbean Sea. The holotype collection of $L$. carpoklonium is a contemporary collection housed at MSM and includes air-dried tetrasporangial and gametangial specimens (Athanasiadis \& Ballantine 2011).

The close relationship between specimens from the GMx and specimens from offshore Brazil (Lithothamnion sp. I) indicates that names applied to taxa from areas in or near Brazilian waters should also be considered for specimens collected throughout the GMx. Surface views of the epithallial cells and of multiporate conceptacles (which show depressions around each pore) of Lithothamnion sp. A (LAF6549) are similar to the SEM images of a specimen identified as L. crispatum from the northeastern coast of Brazil (Costa et al. 2014, see p. 146, figs. 8D, G, H), and surface views of the epithallial cells are also similar to SEM images of a specimen identified as $L$. brasiliense Foslie (Costa et al. 2014, p. 148 fig. 9C). DNA sequencing of L. brasiliense, collected from São Sebastiao, Brazil and housed at TRH (Woelkerling et al. 2005) may help clarify if this species is related to taxa from the GMx. Mariath et al. (2012) recently described a protuberant crustose species from Bahia, Brazil that grows in shallow water on corals, Lithothamnion steneckii Mariath and Figueiredo. This specimen also shows the habit of Lithothamnion sp. B. DNA sequencing of the holotype specimen of $L$. steneckii is likely not possible due to formalin preservation (Mariath et al. 2012); however, DNA sequencing of topotype collections may be an informative alternative.

Epithallial cells. Terminology referring to the type of epithallial cells considered diagnostic for Lithothamnion has been used inconsistently in coralline literature. Adey (1966, p. 364) first described that the uppermost portion of the lateral cell walls of epithallial cells "tend to flare-out" (Adey, 1966 p. 329). The terms "flattened and flared" (Woelkerling, 1988, Harvey et al. 2003) and "flared" (Peña et al. 2014, Oliveira-Costa et al. 2014, Mariath et al. 2012, Robinson et al. 2013) appear most widely in recent coralline literature, but these cells also have been referred to as being "eared" (Johansen, 1976, Johansen 1981), "angular" (Johansen 1976, Woelkerling 1983), and "armored" (with heavy calcification and thick walls) (Adey et al. 2015). Because not all species of Lithothamnion show a pronounced trapezoidal-shaped lumen (Adey et al. 2005) the term "armored" was applied in this study.

The epithallial cell roof is sometimes absent in published SEM images of Lithothamnion spp. (Adey et al. 2005, p.1016, fig. 7C; Robinson et al. 2013 p.66 fig. 3B, left arrowhead) but may remain intact (Robinson et al. 2013 p.66 
fig. 3B, right, arrowhead) or remain intact but collapse into the cell lumen (Basso et al. 2011, p. 148, fig. 12). The epithallial cell roof possesses a primary pit connection and consists of a cross wall with two layers, one is the layer of the distal end of the intact epithallial cell and the other layer is a remnant of the proximal end of the previously sloughed epithallial cell (Wegeberg \& Pueschel 2002). The results of this study show that the pit connections of the epithallial cell roof can be observed with SEM and that identifying this pit connection can be informative when diagnosing epithallial cell morpho-anatomical structure and in describing potential new species. Furthermore, because the epithallial cell roof may have remnants of the previously shed epithallial cell, careful attention is required when interpreting observed structures. Obtaining both surface views and section views can aid in determining epithallial cell structure.

The unique epithallial cells of Lithothamnion sp. H (LAF6970C) (Fig. 15) that possess very heavily calcified proximal and lateral walls, accounting for more than half of the cell's volume, are herein termed heavily armored. Images of this species are shown in Peña et al. (2014, p. 206 fig. 9D), and the epithallial cells are reported as being "flared" in the figure legend (p. 205) but further described as having "somewhat flared outermost cell walls" (p. 205). The images lack good contrast to show the primary pit connections in the epithallial cell roof, however, the small circular roof can be seen in surface view and one cell (second from the right, left of the cell indicated by the arrow) shows the thick lateral cell walls small round lumen possessed by this species. Images of epithallial cells of additional specimens of this species are needed to clarify if the presence of this heavily armored epithallium is a diagnostic character, and at what taxonomic level it is informative.

Mineral infill in Lithothamnion. Mineral infill within empty conceptacles in the form of aragonite is a common occurrence in Lithothamnion specimens from the GMx (Figs. 7, 8, 9, 13) and Panama (Fig. 15). Images of Lithothamnion sp. I (Fig. 13) illustrate the infill of needle-like crystals in empty, overgrown conceptacles, and images of Lithothamnion sp. J (Fig. 15) illustrate the infill of spherical masses that were confirmed with analyses of SEM-EDS (energy dispersive spectrometry) and x-ray diffraction data to be aragonite (Krayesky-Self et al. 2016). This infilling has been speculated to be associated with the development of the secondary hypothallium that grows over empty conceptacles (KrayeskySelf et al. 2016), shown herein to be a common developmental pattern in Lithothamnion.

Intercalary Meristematic Cells. The size of the intercalary meristematic cells, "as long or longer than their immediate inward derivatives" (Woelkering 1988, p. 171), also has been reported to be one of the defining characters of Lithothamnion (Adey 1966, Woelkering 1988, p. 171). Adey described this as resulting from "perithallial cells nearly maximum length before being cut-off from the meristem" (Adey 1966, p. 323). However, in their study of collections from Guadeloupe, F.W.I., Peña et al. (2014b) reported that specimens identified as Lithothamnion spp. (Fig. 3, 4, 5) possessed putative meristematic cells that were often shorter than the inward derivatives. Meristematic cells that were approximately the same size as their inward derivatives were also reported by Athanasiadis \& Ballantine (2011) in L. carpoklonium. In this study, meristematic cells were as approximately as long or longer than their immediate inward derivatives for some specimens (Figs. 9, 11, 12). However, other specimens showed meristematic cells that were smaller than their perithallial derivatives (Figs. 6, 7, 8, 13, 15, S4). One species (Lithothamnion sp. I), showed that the meristematic cells can be longer than (Fig. 12), approximately equal in size to (Fig. 14), or shorter than (Fig. 13) their perithallial derivatives, indicating that 1) the size of meristematic cells and perithallial derivatives may not be taxonomically informative and that 2) elongation of perithallial derivatives may continue after being cut-off from the meristem. Integrated studies involving multiple types of microscopy conducted on both calcified and uncalcified specimens may elucidate the developmental pattern of meristematic activity in the Corallinophycidae.

\section{Acknowledgements}

This research was made possible in part by a Coastal Water Consortium of The Gulf of Mexico Research Initiative (GoMRI-I), and GoMRI-III, following the 2010 Macondo oil spill. We thank the National Science Foundation (DEB0315995, DEB-1027110) for pre- and post-Deepwater Horizon oil spill biodiversity research in the Gulf of Mexico. We also thank NSF ARTS grant DEB-1455569 for research on rhodoliths from Panama. We thank Darryl Felder and Nancy Rabalais for their support and interest, the crew of the R/V Pelican, especially Alex Ren, for their help with sampling protocols aboard ship, and present and former members of the UL Lafayette Seaweeds Lab for help with sampling protocols. We greatly acknowledge Tom Pesacreta and Mike Purpurea at the UL Lafayette Microscopy Center for help and advice while using the SEM. Talita Vieira-Pinto and Mariana Oliveira thank support from FAPESP (201311833-3, 2012/05076-2 and 2014/13386-7) and CNPq (Br BOL-564945-2010-2). 


\section{References}

Adey, W.H. (1966) The genera Lithothamnium, Leptophytum (nov. gen.) and Phymatolithon in the Gulf of Maine. Hydrobiologia 28: $321-370$.

http://dx.doi.org/10.1007/BF00130389

Adey, W.H., Chamberlain, Y.M. \& Irvine, L.M. (2005) An SEM-based analysis of the morphology, anatomy, and reproduction of Lithothamnion tophiforme (Esper) Unger (Corallinales, Rhodophyta), with a comparative study of associated North Atlantic arctic/ subarctic Melobesioideae. Journal of Phycology 41: 1010-1024.

http://dx.doi.org/10.1111/j.1529-8817.2005.00123.x

Adey, W.H., Hernandez-Kantun, J.J., Johnson, G. \& Gabrielson, P.W. (2015) DNA sequencing, anatomy, and calcification patterns support a monophyletic, subarctic, carbonate reef-forming Clathromorphum (Hapalidiaceae, Corallinales, Rhodophyta). Journal of Phycology 51: 189-203.

http://dx.doi.org/10.1111/jpy.12266

Athanasiadis, A. \& Ballantine, D.L. (2011) Lithothamnion carpoklonion sp. nov. (Melobesioideae, Corallinales, Rhodophyta) from Puerto Rico, Caribbean Sea: an epiphytic encrusting coralline alga producing conceptacle protuberances. Botanica Marina 54: $403-410$. http://dx.doi.org/10.1515/bot.2011.047

Bahia, R.G., Amado-Filho, G.M., Maneveldt, G.W., Adey, W.H., Johnson, G., Marins, B.V. \& Longo, L.L. (2014) Sporolithon tenue sp. nov. (Sporolithales, Corallinophycidae, Rhodophyta): A new rhodolith-forming species from the tropical southwestern Atlantic. Phycological Research 62: 44-54.

http://dx.doi.org/10.1111/pre.12033

Basso, D., Rodondi, G. \& Bressan, G. (2011) A re-description of Lithothamnion crispatum and the status of Lithothamnion superpositum (Rhodophyta, Corallinales). Phycologia 50: 144-155. http://dx.doi.org/10.2216/10-20.1

Bittner, L., Payri, C.E., Maneveldt, G.W., Couloux, A., Cruaud, C., De Reviers, B. \& Le Gall, L. (2011) Evolutionary history of the Corallinales (Corallinophycidae, Rhodophyta) inferred from nuclear, plastidial and mitochondrial genomes. Molecular Phylogenetics and Evolution 61: 697-713.

http://dx.doi.org/10.1016/j.ympev.2011.07.019

Bouckaert, R., Heled, J., Kühnert, D., Vaughan, T., Wu, C.H., Xie, D., Suchard, M.A., Rambaut, A. \& Drummond, A.J. (2014) BEAST 2: a software platform for Bayesian evolutionary analysis. PLoS Computational Biology10: e1003537.

http://dx.doi.org/10.1371/journal.pcbi.1003537

Dawes, C.J. (1974) Marine Algae of the West Coast of Florida. University of Miami Press, Miami, Florida, 201 pp.

Delbeek, J.C. \& Sprung, J. (2005) The Reef Aquarium, Vol. 3: Science, Art, and Technology. Coconut Grove, Two Little Fishies, Inc., d.b.a. Ricordea Publishing, 680 pp.

Edwards, P. \& Kapraun, D.F. (1973) Benthic marine algal ecology in Port Aransas, Texas area. Contributions Marine Science 17: 15-52. Felder, D.L., Thoma, B.P., Schmidt, W.E., Sauvage, T., Self-Krayesky, S., Chistoserdov, A., Bracken-Grissom, H. \& Fredericq, S. (2014) Seaweeds and decapod crustaceans on Gulf deep banks after the Macondo Oil Spill. Bioscience 64: 808-819. http://dx.doi.org/10.1093/biosci/biu119

Foster, M.S. (2001) Rhodoliths: between rocks and soft places. Journal of Phycology 37: 659-667. http://dx.doi.org/10.1046/j.1529-8817.2001.00195.x

Fredericq, S., Cho, T.O., Earle, S.A., Gurgel, C.F., Krayesky, D.M., Mateo-Cid, L.E., Mendoza Gonzáles, A.C., Norris, J.N. \& Suárez, A.M. (2009) Seaweeds of the Gulf of Mexico. In: Felder, D.L. \& Camp, D.K. (Eds.) Gulf of Mexico: Its Origins, Waters, and Biota. I. Biodiversity. Texas A\&M Univ. Press, pp. 187-259.

Fredericq, S., Arakaki, N. Camacho, O., Gabriel, D. Krayesky, D., Self-Krayesky, S., Rees, G., Richards, J., Sauvage, T., Venera-Ponton, D. \& Schmidt, W.E. (2014) A dynamic approach to the study of rhodoliths: a case study for the Northwestern Gulf of Mexico. Cryptogamie, Algologie 35: 77-98. http://dx.doi.org/10.7872/crya.v35.iss 1.2014 .77

Fujisawa, T. \& Barraclough, T.G. (2013) Delimiting species using single-locus data and the Generalized Mixed Yule Coalescent (GMYC) approach: a revised method and evaluation on simulated datasets. Systematic Biology 62: 707-724.

http://dx.doi.org/10.1093/sysbio/syt033

Gore, R.H. (1992) The Gulf of Mexico: a Treasury of Resources in the American Mediterranean. Pineapple Press, Sarasota, Florida, 384 pp.

Harvey, A.S., Woelkerling, W.J. \& Millar, A.J. (2003) An account of the Hapalidiaceae (Corallinales, Rhodophyta) in south-eastern Australia. Australian Systematic Botany 16: 647-698. 
http://dx.doi.org/10.1071/SB03008

Hernández-Kantún, J.J., Gabrielson, P., Hughey, J.R., Pezzolesi, L., Rindi, F., Robinson, N.M., Peña, V., Riosmena-Rodriguez, R., Le Gall, L. \& Adey, W. (2016) Reassessment of branched Lithophyllum spp. (Corallinales, Rhodophyta) in the caribbean Sea with global implications. Phycologia 55 (6): 619-639.

Hernández-Kantún, J.J., Riosmena-Rodriguez, R., Hall-Spencer, J.M., Peña, V., Maggs, C.A. \& Rindi, F. (2015) Phylogenetic analysis of rhodolith formation in the Corallinales (Rhodophyta). European Journal of Phycology 50: 46-61. http://dx.doi.org/10.1080/09670262.2014.984347

Heydrich, F. (1897b) Melobesiae. Berichte der Deutschen botanischen Gesellschaft 15: 403-420, pl. 18.

Hind, K.R. \& Saunders, G.W. (2013) A molecular phylogenetic study of the tribe Corallineae (Corallinales, Rhodophyta) with an assessment of genus-level taxonomic features and descriptions of novel genera. Journal of Phycology 49: 103-114. http://dx.doi.org/10.1111/jpy.12019

Hind, K.R., Miller, K.A., Young, M., Jensen, C., Gabrielson, P.W. \& Martone, P.T. (2015) Resolving cryptic species of Bossiella (Corallinales, Rhodophyta) using contemporary and historical DNA. American Journal of Botany 102: 1912-1930. http://dx.doi.org/10.3732/ajb.1500308

Irvine, L.M. \& Chamberlain, Y.M. (1994) Seaweeds of the British Isles. Vol. 1, Rhodophyta, Part 2B. Corallinales, Hildenbrandiales. The Natural History Museum, London, 276 pp.

Johansen, H.W. (1976) Current status of generic concepts in coralline algae (Rhodophyta). Phycologia 15: 221-244. http://dx.doi.org/10.2216/i0031-8884-15-2-221.1

Johansen, H.W. (1981) Coralline Algae, a First Synthesis. CRC press, Boca Raton, Florida, 239 pp.

Joyce, E.A. \& Williams, J. (1969) Rationale and pertinent data. Memoirs of the Hourglass Cruises 1: 11-50.

Krayesky-Self, S., Richards, J.L., Rahmatian, M. \& Fredericq, S. (2016) Aragonite infill in overgrown conceptacles of coralline Lithothamnion spp. (Hapalidiaceae, Hapalidiales, Rhodophyta): new insights in biomineralization and phylomineralogy. Journal of Phycology 52: 161-173.

http://dx.doi.org/10.1111/jpy.12392

Lanfear, R., Calcott, B., Ho, S.Y.W. \& Guindon, S. (2012) PartitionFinder: combined selection of partitioning schemes and substitution models for phylogenetic Analyses. Molecular Biology and Evolution 29: 1695-1701. http://dx.doi.org/10.1093/molbev/mss020

Maddison, D.R. \& Maddison, W.P. (2000) MacClade4: Analysis of Phylogeny and Character Evolution. Version 4.0. Sinauer Associates, Sunderland, MA.

Maia, V.H., Da Mata, C.S., Franco, L.O., Cardoso, M.A., Cardoso, S.R.S., Hemerly, A.S. \& Ferreira, P.C.G. (2012) DNA barcoding Bromeliaceae: achievements and pitfalls. PLoS One 7: e29877. http://dx.doi.org/10.1371/journal.pone.0029877

Mariath, R., Riosmena-Rodriguez, R. \& Figueiredo, M. (2012) Lithothamnion steneckii sp. nov. and Pneophyllum conicum: new coralline red algae (Corallinales, Rhodophyta) for coral reefs of Brazil. Algae 27: 249-258.

http://dx.doi.org/10.4490/algae.2012.27.4.249

Mason, L.R. (1953) The crustaceous coralline algae of the Pacific Coast of the United States, Canada and Alaska. University of California Publications in Botany 26: 313-390.

Mateo-Cid, L.E., Mendoza-González, A.C. \& Gabrielson, P.W. (2014a) Neogoniolithon (Corallinales, Rhodophyta) on the Atlantic coast of Mexico, including N. siankanensis sp. nov. Phytotaxa 190 (1): 64-93.

http://dx.doi.org/10.11646/phytotaxa.190.1.7

Mateo-Cid, L.E., Mendoza-González, A.C. \& García-López, D.Y. (2014b) Systematic survey of Lithothamnion, Melobesia and Mesophyllum species (Hapalidiaceae, Corallinales, Rhodophyta) recorded along the Atlantic coast of Mexico. Phytotaxa 164 (4): 226-238. http://dx.doi.org/10.11646/phytotaxa.164.4.2

Miller, M.A., Pfeiffer, W. \& Schwartz, T. (2010) Creating the CIPRES Science Gateway for inference of large phylogenetic trees in Proceedings of the Gateway Computing Environments Workshop (GCE), 14 Nov. 2010. New Orleans, LA, pp. 1-8.

Minnery, G.A. (1990) Crustose coralline algae from the Flower Garden Banks, Northwestern Gulf of Mexico; controls on distribution and growth morphology. Journal of Sedimentary Research 60: 992-1007. http://dx.doi.org/10.1306/d4267663-2b26-11d7-8648000102c1865d

Nelson, W.A., Sutherland, J.E., Farr, T.J., Hart, D.R., Neill, K.F., Kim, H.J. \& Yoon, H.S. (2015) Multi-gene phylogenetic analyses of New Zealand coralline algae: Corallinapetra novaezelandiae gen. et sp. nov. and recognition of the Hapalidiales ord. nov. Journal of Phycology 51: 454-468.

http://dx.doi.org/10.1111/jpy.12288

Oliveira Costa, I., Horta, P.A., Bergstrom, E.R. \& Nunes, J.M.C. (2014) Taxonomic study of crustose coralline algae off the northeastern 
Brazilian coast. Phytotaxa 190 (1): 130-161.

http://dx.doi.org/10.11646/phytotaxa.190.1.10

Paradis, E., Claude, J. \& Strimmer, K. (2004) APE: analyses of phylogenetics and evolution in R language. Bioinformatics 20: $289-290$. http://dx.doi.org/10.1093/bioinformatics/btg412

Pardo, C., Lopez, L., Peña, V., Hernández-Kantún, J., Le Gall, L., Bárbara, I. \& Barreiro, R. (2014) A multilocus species delimitation reveals a striking number of species of coralline algae forming maerl in the OSPAR maritime area. PLoS ONE 9: e104073. http://dx.doi.org/10.1371/journal.pone.0104073

Peña, V., Adey, W.H., Riosmena-Rodríguez, R., Jung, M.Y., Afonso-Carrillo, J., Choi, H.G. \& Barbara, I. (2011) Mesophyllum sphaericum sp. nov. (Corallinales, Rhodophyta): A new maërl-forming species from the northeast Atlantic. Journal of Phycology 47: 911-927. http://dx.doi.org/10.1111/j.1529-8817.2011.01015.x

Peña, V., Hernández-Kantún, J.J., Grall, J., Pardo, C., López, L., Bárbara, I., Le Gall, L \& Barreiro, R. (2014a) Detection of gametophytes in the maerl-forming species Phymatolithon calcareum (Melobesioideae, Corallinales) assessed by DNA barcoding. Cryptogamie, Algologie 35: 15-25. http://dx.doi.org/10.7872/crya.v35.iss1.2014.15

Peña, V., Rousseau, F., De Reviers, B. \& Le Gall, L. (2014b) First assessment of the diversity of coralline species forming maerl and rhodoliths in Guadeloupe, Caribbean using an integrative systematic approach. Phytotaxa 190 (1): 190-215. http://dx.doi.org/10.11646/phytotaxa.190.1.13

Peña, V., Pardo, C., López, L., Carro, B., Hernandez-Kantun, J., Adey, W.H., Bárbara, I. Barreiro, R. \& Le Gall, L. (2015) Phymatolithon lusitanicum sp. nov. (Hapalidiales, Rhodophyta): the third most abundant maerl-forming species in the Atlantic Iberian Peninsula. Cryptogamie, Algologie 36: 429-459.

http://dx.doi.org/10.7872/crya/v36.iss4.2015.429

Puillandre, N., Lambert, A., Brouillet, S. \& Achaz, G. (2012) ABGD, Automatic Barcode Gap Discovery for primary species delimitation. Molecular Ecology 21: 1864-1877. http://dx.doi.org/10.1111/j.1365-294X.2011.05239.x

R Core Team (2014) R: A language and Environment for Statistical Computing. R Foundation for Statistical Computing, Vienna, Australia. Available from: www.R-project.org (accessed 1 October 2016)

Rambaut, A., Suchard, M.A., Xie, D. \& Drummond, A.J. (2014) Tracer v1.6. Available from: http://beast.bio.ed.ac.uk/Tracer (accessed 1 October 2016)

Richards, J.L. (2016) Systematics of Rhodolith-Forming Taxa of Corallinophycidae (Rhodophyta) from the Northwestern Gulf of Mexico and Panama. ProQuest, Ann Arbor, Michigan, $257 \mathrm{pp.}$

Richards, J.L., Gabrielson, P.W. \& Fredericq, S. (2014) New Insights into the genus Lithophyllum (Lithophylloideae, Corallinaceae, Corallinales) from deepwater rhodolith beds offshore the NW Gulf of Mexico. Phytotaxa 190 (1): 162-175. http://dx.doi.org/10.11646/phytotaxa.190.1.11

Robinson, N.M., Hansen, G.I., Fernández-García, C. \& Riosmena-Rodríguez, R. (2013) A taxonomic and distributional study of the rhodolith-forming species Lithothamnion muelleri (Corallinales, Rhodophyta) in the Eastern Pacific Ocean. Algae 28: 63-71. http://dx.doi.org/10.4490/algae.2013.28.1.063

Ronquist, F., Teslenko, M., van der Mark, P., Ayres, D. L., Darling, A., Höhna, S., Larget, B., Liu, L., Suchard, M.A. \& Huelsenbeck, J.P. (2012) MrBayes 3.2: efficient Bayesian phylogenetic inference and model choice across a large model space. Systematic Biology 61: $539-542$.

http://dx.doi.org/10.1093/sysbio/sys029

Saunders, G.W. (2005) Applying DNA barcoding to red macroalgae: a preliminary appraisal holds promise for future applications. Philosophical Transactions of the Royal Society B: Biological Sciences 360: 1879-1888. http://dx.doi.org/10.1098/rstb.2005.1719

Saunders, G.W. (2014) Long distance kelp rafting impacts seaweed biogeography in the Northeast Pacific: the kelp conveyor hypothesis. Journal of Phycology 50: 968-974. http://dx.doi.org/10.1111/jpy.12237

Sherwood, A.R. \& Presting, G.G. (2007) Universal primers amplify a 23s rDNA plastid marker in eukaryotic algae and Cyanobacteria. Journal of Phycology 43: 605-608. http://dx.doi.org/10.1111/j.1529-8817.2007.00341.x

Sherwood, A., Kurihara, A., Conklin, K., Sauvage, T. \& Presting, G. (2010) The Hawaiian Rhodophyta Biodiversity Survey (2006-2010): a summary of principal findings. BMC Plant Biology 10: 258.

http://dx.doi.org/10.1186/1471-2229-10-258

Sissini, M.N., Oliveira, M.C., Gabrielson, P.W., Robinson, N.M., Okolodkov, Y.B., Riosmena-Rodríguez, R. \& Horta, P.A. (2014) Mesophyllum erubescens (Corallinales, Rhodophyta)—so many species in one epithet. Phytotaxa 190 (1): 299-319. 
http://dx.doi.org/10.11646/phytotaxa.190.1.18

Stamatakis, A. (2006) RAxML-VI-HPC: Maximum likelihood-based phylogenetic analyses with thousands of taxa and mixed models. Bioinformatics 22: 2688-2690.

http://dx.doi.org/10.1093/bioinformatics/btl446

Tamura, K., Peterson, D., Peterson, N., Stecher, G., Nei, M. \& Kumar, S. (2011) MEGA5: molecular evolutionary genetics analysis using maximum likelihood, evolutionary distance, and maximum parsimony methods. Molecular Biology and Evolution 28: 2731-2739. http://dx.doi.org/10.1093/molbev/msr121

Taylor, W.R. (1960) Marine Algae of the Eastern Tropical and Subtropical coasts of the Americas. Ann Arbor, The University of Michigan Press 870 pp.

Thompson, J.D., Higgins, D.G. \& Gibson, T.J. (1994) CLUSTAL W: improving the sensitivity of progressive multiple sequence alignment through sequence weighting, position-specific gap penalties and weight matrix choice. Nucleic Acids Research 22: 4673-4680. http://dx.doi.org/10.1093/nar/22.22.4673

Thiers, B. (2016) [continuously updated] Index Herbariorum: A global directory of public herbaria and associated staff. New York Botanical Garden's Virtual Herbarium. Available from: http://sweetgum.nybg.org/ih/ (accessed 1 October 2016)

Turgeon, D.D., Lyons, W.G., Mikkelsen, P., Rosenberg, G. \& Moretzsohn, F. (2009) Bivalvia (Mollusca) of the Gulf of Mexico. In: Felder, D.L. \& Camp, D.K. (Eds.) Gulf of Mexico: Its Origins, Waters, and Biota. I. Biodiversity. Texas A\&M Univ. Press, pp. $187-259$.

Vaidya, G., Lohman, D.J. \& Meier, R. (2011) SequenceMatrix: concatenation software for the fast assembly of multigene datasets with character set and codon information. Cladistics 27: 171-180.

http://dx.doi.org/10.1111/j.1096-0031.2010.00329.x

Vieira-Pinto, T., Oliveira, M.C., Bouzon, J., Sissini, M., Richards, J.L., Riosmena-Rodríguez, R. \& Horta, P.A. (2014) Lithophyllum species from Brazilian coast: range extension of Lithophyllum margaritae and description of Lithophyllum atlanticum sp. nov. (Corallinales, Corallinophycidae, Rhodophyta). Phytotaxa 190 (1): 355-369. http://dx.doi.org/10.11646/phytotaxa.190.1.21

Wegeberg, S. \& Pueschel, C.M. (2002) Epithallial and initial cell fine structure in species of Lithothamnion and Phymatolithon (Corallinales, Rhodophyta). Phycologia 41: 228-244.

http://dx.doi.org/10.2216/i0031-8884-41-3-228.1

Woelkerling, W.J. (1983) A taxonomic reassessment of Lithothamnium (Corallinaceae, Rhodophyta) based on studies of RA Philippi's original collections. British Phycological Journal 18: 165-197.

http://dx.doi.org/10.1080/00071618300650211

Woelkerling, W.J. (1988) The Coralline Red Algae: An Analysis of Genera and Subfamilies of Nongeniculate Corallinaceae. British Museum (Natural History), London, Oxford University Press, Oxford, New York 268 pp.

Woelkerling, W.J., Gustavsen, G., Myklebost, H.E., Prestø, T. \& Såstad, S.M. (2005) The coralline red algal herbarium of Mikael Foslie: revised catalogue with analyses. Gunneria 77: 1-625. Available from: http://hdl.handle.net/11250/273026 (accessed 1 October 2016)

Yoon, H.S., Hackett, J.D. \& Bhattacharya, D. (2002) A single origin of the peridinin-and fucoxanthin-containing plastids in dinoflagellates through tertiary endosymbiosis. Proceedings of the National Academy of Sciences USA 99: 11724-11729.

http://dx.doi.org/10.1073/pnas.172234799 